\title{
Approaches towards the synthesis of 5-aminopyrazoles
}

\author{
Ranjana Aggarwal ${ }^{* 1}$, Vinod Kumar ${ }^{2}$, Rajiv Kumar ${ }^{1}$ and Shiv P. Singh ${ }^{1}$
}

\section{Review}

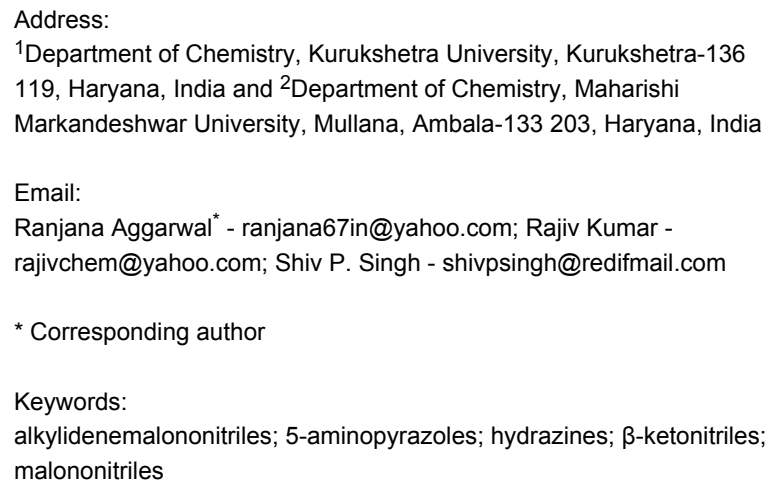

${ }^{1}$ Department of Chemistry, Kurukshetra University, Kurukshetra-136 119, Haryana, India and ${ }^{2}$ Department of Chemistry, Maharishi Markandeshwar University, Mullana, Ambala-133 203, Haryana, India

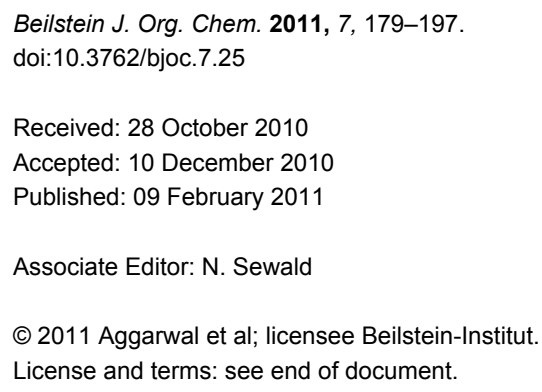

\section{Abstract}

The biological and medicinal properties of 5-aminopyrazoles have prompted enormous research aimed at developing synthetic routes to these heterocyles. This review focuses on the biological properties associated with this system. Various synthetic methods developed up to 2010 for these compounds are described, particularly those that involve the reactions of $\beta$-ketonitriles, malononitrile, alkylidenemalononitriles and their derivatives with hydrazines, as well as some novel miscellaneous methods.

\section{Review}

The 5-aminopyrazole system represents an important heterocyclic template that has attracted considerable interest because of its long history of application in the pharmaceutical and agrochemical industries [1-4]. These compounds have been extensively investigated over the past one hundred years and their chemistry has been reviewed in two books published in 1964 [5] and in 1967 [6].

Structurally simple 5-amino-1-tert-butylpyrazole-4-carboxamide I was found to inhibit p56 Lck [7] (Figure 1). 5-Amino1-(4-methylphenyl) pyrazole II has been tested as an NPY5 antagonist [8]. 5-Amino-4-benzoyl-3-methylthio-1-(2,4,6trichlorophenyl)pyrazole III has been reported as a potent corticotrophin-releasing factor-1 (CRF-1) receptor antagonist [9]. 5-Amino-1-(2,6-dichloro-4-(trifluoromethyl)phenyl)-4-(3methoxyphenyl)-3-methylthiopyrazole IV has been described as a potent GABA inhibitor with selectivity towards insect versus mammalian receptors [10]. The simple $N$-phenyl amide of 5-amino -1,3-dimethylpyrazole-4-carboxylic acid $\mathbf{V}$ has been shown to exhibit antifungal activity [11] (Figure 1). The 5-amino-1-pyrazinyl-3-carboxamidopyrazole derivative VI has been recently reported as a potent antibacterial agent with a 
very broad spectrum [12]. Recently, components of the mitotic machinery have been targeted in an attempt to develop novel anticancer agents. These include critical signaling kinases such as the Aurora, PLK, and the cyclin-dependent kinases (CDK). Compound VII (AZD1152) is the first Aurora-B selective inhibitor to enter clinical trials [13] (Figure 1).<smiles>CC(C)(C)n1nc(-c2ccc(Cl)cc2)c(C(N)=O)c1N</smiles>

I p56 Lck inhibitor $\mathrm{Cl}$<smiles>Cc1nn(-c2c(Cl)cc(Cl)cc2Cl)c(N)c1C(=O)c1ccccc1Cl</smiles>
III CRF-1 antagonist<smiles>Cc1nn(C)c(N)c1C(=O)Nc1ccccc1</smiles>

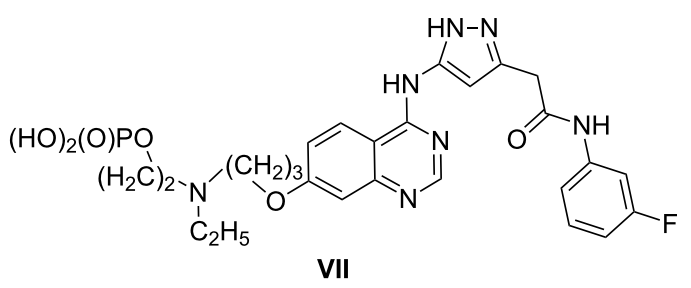

AZD1152
Figure 1: Pharmacologically active 5-aminopyrazoles.

Besides the importance of 5-aminopyrazoles as biologically active agents, they are also useful synthons and building blocks for many heterocyclic products and can act as a binucleophile [14-18]. Cyclocondensation of 5-aminopyrazoles with 1,3- dielectrophiles has been extensively used for the preparation of bicyclic nitrogen heterocycles, especially in the preparation of condensed heterocycles such as pyrazolo[3,4- $d]$ pyrimidines, pyrazolo[3,4-b]pyridines, imidazopyrazoles etc.

In view of significant interest in the synthesis of these heterocyclics, we herein report a detailed account of the synthetic methods available for 5-aminopyrazoles.

As pyrazole derivatives do not exist in nature, probably, due to the difficulty in the construction of $\mathrm{N}-\mathrm{N}$ bond by living organisms, their availability depends on the synthetic methods. A large number of synthetic methods have recently appeared. Some of the important methods are outlined below.

\section{Reaction of $\beta$-ketonitriles with hydrazines}

The most versatile method available for the synthesis of 5 -aminopyrazoles involves the condensation of $\beta$-ketonitriles with hydrazines. $\beta$-Ketonitriles 1 react smoothly with hydrazines to yield 5-aminopyrazoles 3 [19-28]. The reaction apparently involves the nucleophilic attack of the terminal nitrogen of the hydrazine on the carbonyl carbon with the formation of hydrazones $\mathbf{2}$, which subsequently undergo cyclization by the attack of the other nitrogen on the nitrile carbon to produce 5-aminopyrazoles 3 (Scheme 1). Utilizing this reaction, a large number of 5-amino-1-heteroarylpyrazoles have been synthesized in our laboratory by the reaction of several heteroarylhydrazines with $\alpha$-cyanoacetophenones [29,30]. The intermediate hydrazones $\mathbf{2}$ are rarely isolated, though their formation has been reported in the reaction of 2-nitro/2,4-dinitrophenylhydrazines and aryl- $\alpha$-cyanoacetaldehydes $\mathbf{1}\left(\mathrm{R}^{2}=\right.$ aryl, $\left.\mathrm{R}^{1}=\mathrm{H}\right)[31]$.

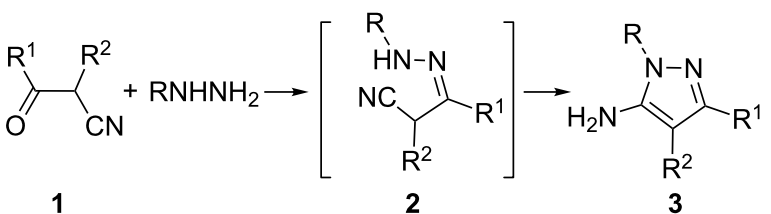

$$
\begin{aligned}
& \mathrm{R}=\text { alkyl, aryl, heteroaryl; } \mathrm{R}^{1}, \mathrm{R}^{2}=\mathrm{H} \text {, alkyl, aryl }
\end{aligned}
$$

Scheme 1: General equation for the condensation of $\beta$-ketonitriles with hydrazines.

Recently, the synthesis of biologically active 5-amino-1heteroaryl-3-trifluoromethylpyrazoles 6 has been achieved by us by the reaction of trifluoroacetylbenzyl cyanide 4 with heteroarylhydrazines [32]. The reaction of 2-hydrazino-4methylquinoline with $\alpha$-trifluoroacetylbenzyl cyanide $\left(\mathrm{R}=\mathrm{CF}_{3}\right)$ (4) at room temperature afforded the intermediate hydrazone 5. The hydrazone $\mathbf{5}$ was characterized by IR and NMR spec- 
troscopy. The IR spectrum of $\mathbf{5}$ showed a fundamental stretching band due to $\mathrm{C} \equiv \mathrm{N}$ at $2179 \mathrm{~cm}^{-1}$. The ${ }^{19} \mathrm{~F}$ NMR spectrum of compound 5 showed fluorine signal at $\delta-65$ ppm due to $\mathrm{CF}_{3}$ group confirming the formation of hydrazone $\mathbf{5}$, which exists as the $Z$-isomer. From the literature [33], the signal for the $\mathrm{CF}_{3}$ group in trifluoromethylhydrazones appears at $\delta-64$ to $-66 \mathrm{ppm}$ for $Z$-isomers and at $\delta-67$ to $-71 \mathrm{ppm}$ for $E$-isomers. As expected, 5 underwent cyclization in refluxing ethanol to give the corresponding 5-aminopyrazole 6 [32]. $\alpha$-Acetyl/ formylbenzyl cyanide $\left(\mathrm{R}=\mathrm{H} / \mathrm{CH}_{3}\right) 4$ on reaction with heteroarylhydrazines in refluxing ethanol yielded the corresponding 5-amino-4-phenylpyrazoles 6 . These compounds were found to be good antibacterial agents (Scheme 2) [34].

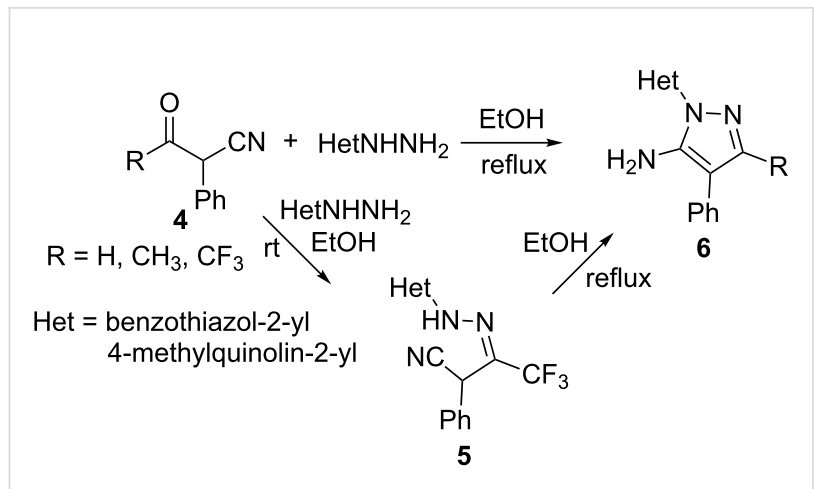

Scheme 2: Reaction of hydrazinoheterocycles with $\alpha$-phenyl- $\beta$ cyanoketones (4).

The isolation of hydrazones $\mathbf{8}$ has also been reported during the condensation of cyanoacetaldehyde (7) with hydrazines [35]. These hydrazones $\mathbf{8}$ were cyclized to the corresponding 5-aminopyrazoles 9 under basic conditions (Scheme 3).

Recently, Kordik et al [36] treated $\alpha$-cyano-4-nitroacetophenone (10) with aryl hydrazines in the presence of triethylamine

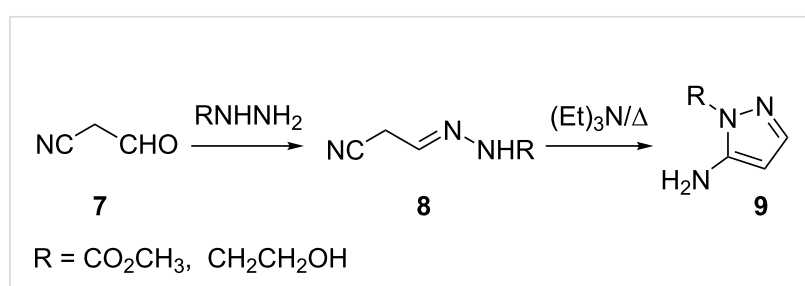

Scheme 3: Condensation of cyanoacetaldehyde (7) with hydrazines

and obtained the corresponding 5-aminopyrazoles $\mathbf{1 1}$ in excellent yields. The latter were further converted into their sulfonamide derivatives $\mathbf{1 2}$ by reducing the nitro group to an amino group by catalytic hydrogenation followed by treatment with an arylsulfonyl chloride (Scheme 4).

Alternatively, 5-aminopyrazoles 17 containing a cyclohexylmethyl- or phenylmethyl- sulfonamido group at position-3 were prepared by treating $\beta$-ketonitriles 16 with a substituted hydrazine in the presence of $\mathrm{Et}_{3} \mathrm{~N}$ in ethanol under reflux conditions. The intermediate $\mathbf{1 6}$ was obtained from $\beta$-ketoester $\mathbf{1 5}$ on treatment with TFA, which in turn was synthesized by condensing 4-(phenylsulfonamidomethyl)cyclohexane carboxylic acid or benzoic acid $\mathbf{1 3}$, respectively, with tert-butyl cyanoacetate (14), as illustrated in Scheme 5 [36].

Baraldi et al. [37] utilized this method for the regioselective synthesis of 2-alkyl- or 2-aryl-3-aminothieno[3,4-c]pyrazoles 19. Several alkyl- or arylhydrazine hydrochlorides on condensation with 4-cyano-3-oxotetrahydrothiophene (18) in refluxing ethanol gave the thienopyrazoles in excellent yields. The regioselectivity of this process has been confirmed by the treatment of 18 with phenylhydrazine, which generated a mixture of intermediate hydrazone 20 and 2-phenyl-3-aminothieno[3,4-c]pyrazole (21) (Scheme 6). Hydrazones 20 on treatment with 5\% $\mathrm{HCl}$ in ethanol underwent cyclization to afford $\mathbf{2 1}$.<smiles>Nc1cc(-c2ccc(NS(=O)(=O)O)cc2)nn1[Al]</smiles>

$\mathrm{Ar}=\mathrm{Ph}, 4-\mathrm{CH}_{3} \mathrm{C}_{6} \mathrm{H}_{4}, 3-\mathrm{CH}_{3} \mathrm{C}_{6} \mathrm{H}_{4}, 4-\mathrm{FC}_{6} \mathrm{H}_{4}, 3-\left(\mathrm{CH}_{3}\right)_{2} \mathrm{NC}_{6} \mathrm{H}_{4}, 3,4-\left(\mathrm{CF}_{3}\right)_{2} \mathrm{C}_{6} \mathrm{H}_{3}$, 1-naphthyl, 2-pyridyl, 4- $\mathrm{CF}_{3}$-2-pyridyl, 4- $\mathrm{CF}_{3}$-2-pyrazine

$\mathrm{Ar}=\mathrm{Ph}, 4-\mathrm{CH}_{3} \mathrm{C}_{6} \mathrm{H}_{4}, 4-\mathrm{CH}_{3} \mathrm{OC}_{6} \mathrm{H}_{4}, 4-\mathrm{FC}_{6} \mathrm{H}_{4}, 4-\mathrm{NO}_{2} \mathrm{C}_{6} \mathrm{H}_{4}, 4-\mathrm{NH}_{2} \mathrm{C}_{6} \mathrm{H}_{4}$, 3- $\left(\mathrm{CH}_{3}\right)_{2} \mathrm{NC}_{6} \mathrm{H}_{4}, 4-\mathrm{CF}_{3} \mathrm{OC}_{6} \mathrm{H}_{4}$, 1-naphthyl 


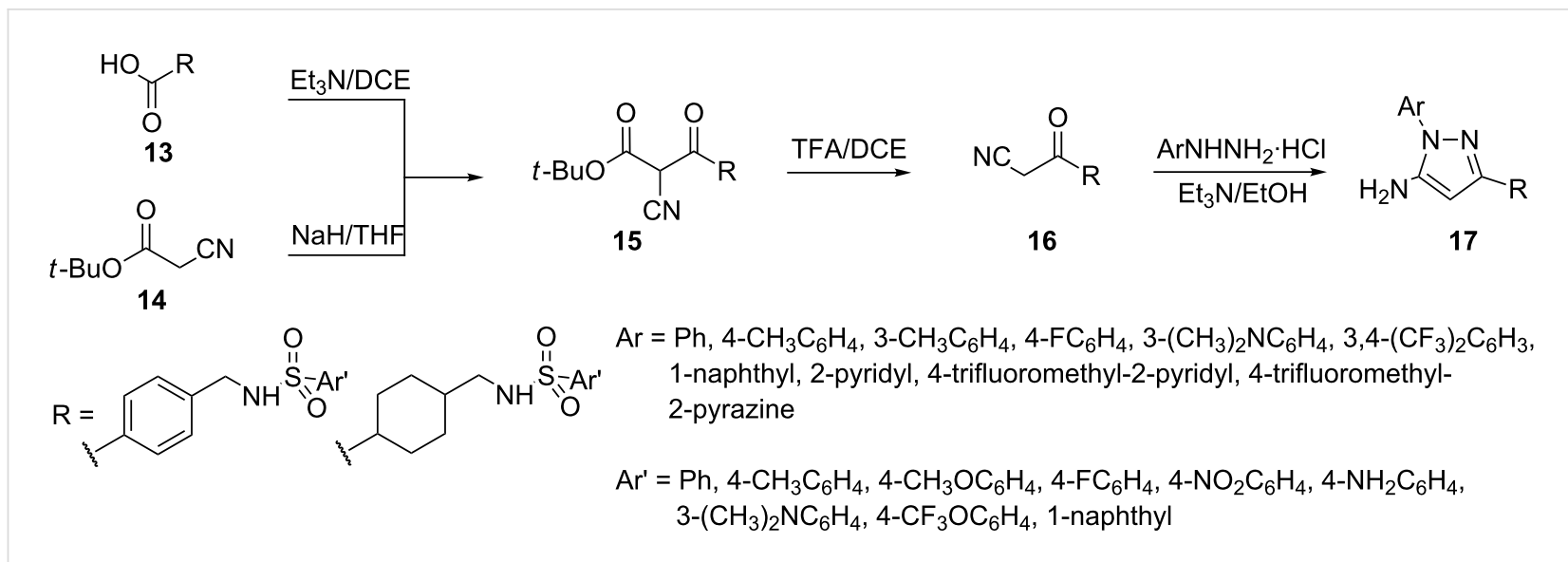

Scheme 5: Synthesis of 5-aminopyrazoles, containing a cyclohexylmethyl- or phenylmethyl- sulfonamido group at position-3.

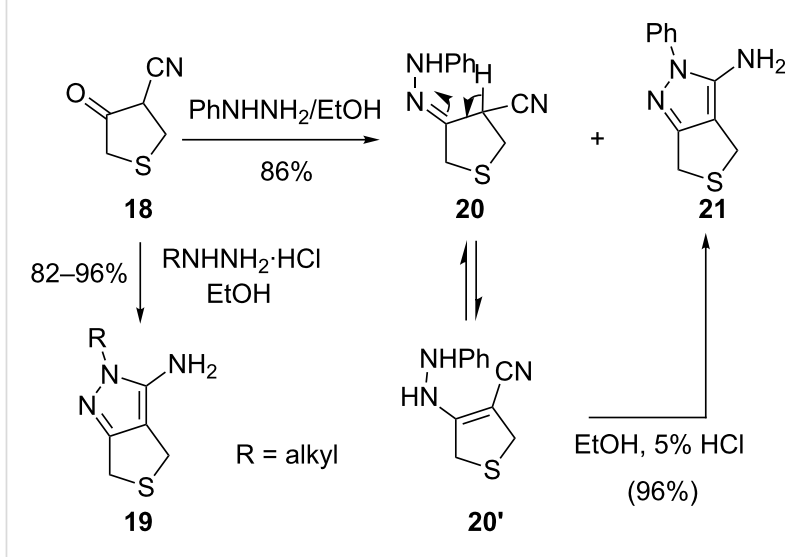

Scheme 6: Regioselective synthesis of 3-amino-2-alkyl (or aryl) thieno[3,4-c]pyrazoles 19.

A novel solid phase synthesis of some 5-aminopyrazoles $\mathbf{2 4}$ and their $N$-acyl and $N$-sulfonyl derivatives has recently been reported by Watson et al. [38] via the resin supported $\beta$-ketoni- triles 22 (Scheme 7). The resin supported aminopyrazoles 23 were hydrolysed to yield $\mathbf{2 4}$ in excellent yields. The synthesis is versatile and affords compoundswith a known pharmacophoric template ideally suited for combinatorial library generation.

Another solid phase synthesis of 5-aminopyrazoles has been reported [39] by utilizing enamine nitrile $\mathbf{2 5}$ as the starting material (Scheme 8). In this reaction, compound 25 was readily hydrolyzed to afford the $\beta$-ketonitrile derivative, i.e., 4-(1cyano-2-oxoethyl)benzamide $\mathbf{2 6}$ which reacted efficiently with hydrazines to give the corresponding 5-aminopyrazoles 27 . Subsequent cleavage from the resin afforded 5-aminopyrazoles 28. This new 5 -aminopyrazole synthesis is more versatile and efficient than its predecessor as it avoids the use of troublesome $\beta$-ketonitrile functionality. This new route is also ideally suited for the synthesis of combinatorial libraries for drug target screening.

In 2009, an efficient three-component, two-step "catch and release" solid-phase synthesis of 3,4,5-trisubstituted pyrazoles

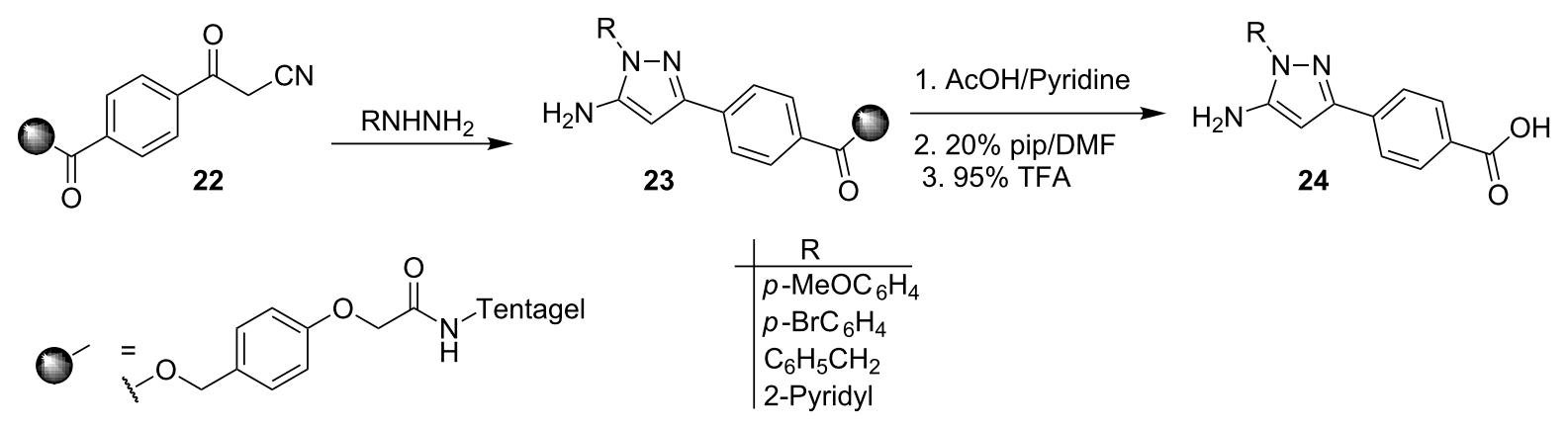




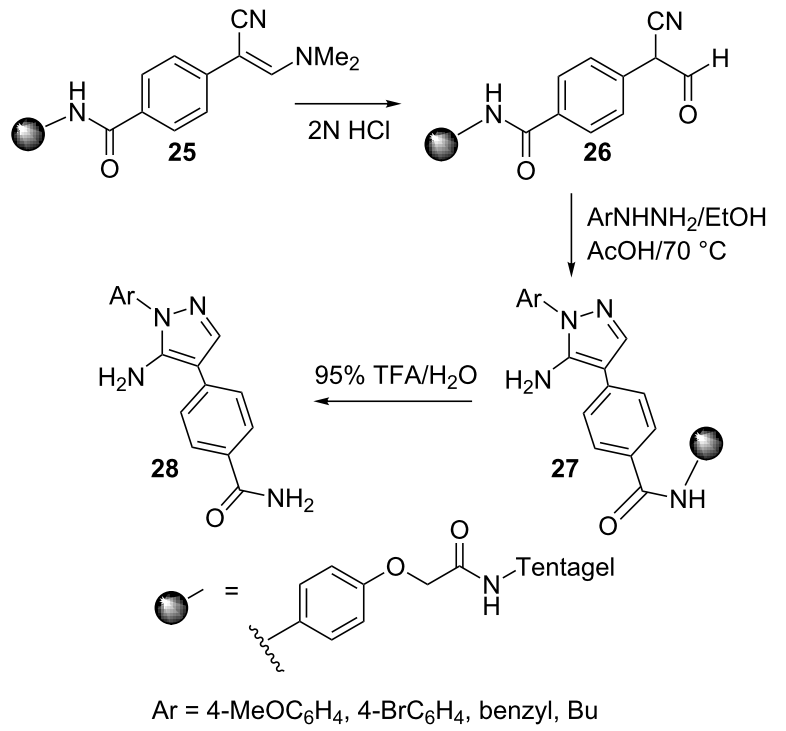

Scheme 8: Synthesis of 5-aminopyrazoles from resin supported enamine nitrile $\mathbf{2 5}$ as the starting material.

was reported which involved a base-promoted condensation of a 2-sulfonyl- or a 2-carbonyl-acetonitrile derivative (29 or $\mathbf{3 3}$ ) with an isothiocyanate and in situ immobilization of the resulting thiolate anion (30 or 34) on Merrifield resin in the first step. Reaction of the resin-bound sulfonyl intermediate $\mathbf{3 1}$ with hydrazine, followed by release from the resin and intramolecular cyclization, afforded 4-arylsulfonyl-3,5-diamino-1H-pyrazoles 32. Reaction of the resin-bound carbonyl intermediate 35 with hydrazine, on the other hand, led to 5-aryl-3-arylamino$1 H$-pyrazole-4-carbonitriles 36, instead of the 5-aminopyrazole 37, which can be rationalized in terms of the higher reactivity of the carbonyl group of $\mathbf{3 5}$ toward hydrazine compared to the cyano group (Scheme 9) [40].

Gao and Lam recently reported a solid-phase synthesis of 5-aminopyrazoles $\mathbf{4 2}$ which were used as precursors for the preparation of pyrazolo[5,1- $d][1,2,3,5]$ tetrazine-4(3H)-ones 43 . Resin 39, obtained from Wang resin 38 and a 5-10 fold excess of $1,1^{\prime}$-carbonyldiimidazole (CDI), was treated with hydrazine hydrate in THF at room temperature to give hydrazide resin $\mathbf{4 0}$, which on further treatment with 2-(1-ethoxyethylidene)malononitrile in ethanol- $\mathrm{CH}_{2} \mathrm{Cl}_{2}(\mathrm{v} / \mathrm{v}$ 1:1) mixture at room temperature for $5 \mathrm{~h}$ provided resin bound 5-aminopyrazole 41 . Resin 41 was easily cleaved with isopropylamine to give crude $\mathbf{4 2}$, which was diazotized with $4 \mathrm{M} \mathrm{HCl}$ and sodium nitrite in water at $0-5{ }^{\circ} \mathrm{C}$ to provide an intermediate diazonium salt. The latter underwent cycloaddition with an isocyanate in a one-pot reaction to give compound 43 (Scheme 10) [41].

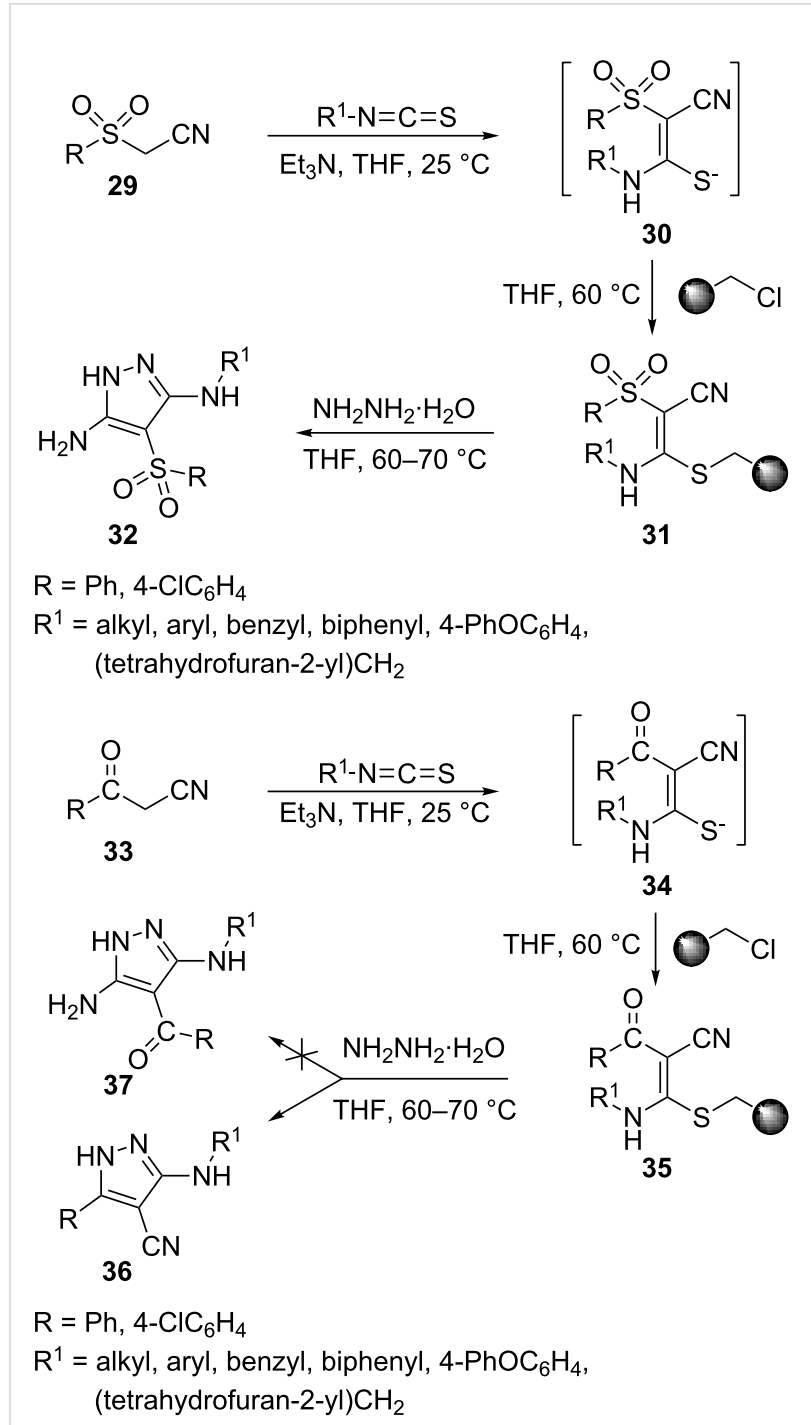

Scheme 9: Two-step "catch and release" solid-phase synthesis of 3,4,5-trisubstituted pyrazoles.

5-Aminopyrazoles 45 have recently been prepared by Boc deprotection of the $\alpha$-hydrazino acids 44 with TFA in methylene chloride followed by condensation with $\beta$-ketonitriles 1 (Scheme 11) [42]. 1-ethyl-3-[3-(dimethylamino)propyl] carbodiimide hydrochloride (EDCI) mediated intramolecular cyclodehydration resulted in the formation of the 5,5-ring system, imidazo[1,2-b]pyrazol-2-one $\mathbf{4 6}$.

3-Oxopropanenitriles 16 on coupling with aromatic diazonium salts gave the corresponding 2-arylhydrazones 47 , which on treatment with hydrazine hydrate formed the 5-amino-4-arylazopyrazoles 48. 3-Oxo-3-(pyrrol-2-yl)propanenitrile (16) reacted with trichloroacetonitrile to yield enamine 49 , which on further treatment with hydrazine hydrate afforded 5-amino-3(pyrrol-2-yl)pyrazole-4-carbonitrile (50) (Scheme 12) [43]. 


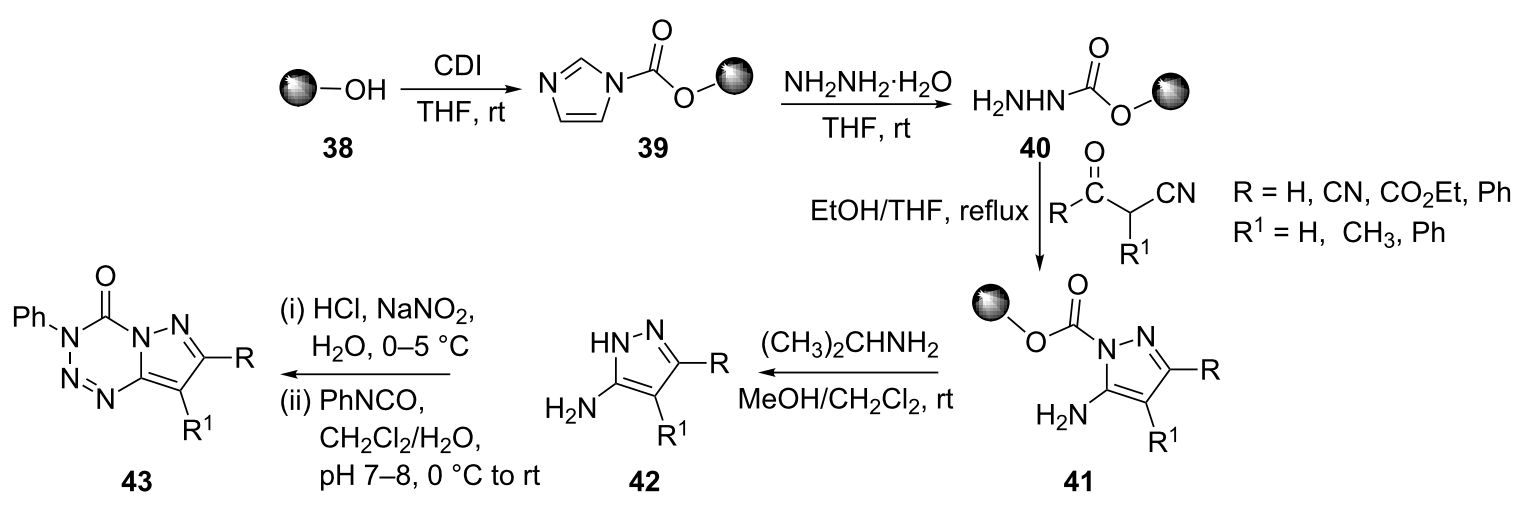<smiles>[R]C(=O)C([R])[N]</smiles>

1

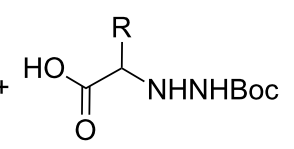

44 (a) and (b) (c)<smiles></smiles>

$\mathrm{R}=\mathrm{H}, i-\mathrm{Pr}, \mathrm{Et}, p-\mathrm{CF}_{3} \mathrm{OC}_{6} \mathrm{H}_{4}$

$\mathrm{R}^{1}=t-\mathrm{Bu}, \mathrm{Ph}, p-\mathrm{CH}_{3} \mathrm{OC}_{6} \mathrm{H}_{4}, p-\mathrm{ClC}_{6} \mathrm{H}_{4}$

$\mathrm{R}^{2}=\mathrm{H}$<smiles>[R]c1nn(C([R])C(=O)O)c(N)c1[R]</smiles>

(a) $50 \%$ TFA-DCM, rt, $1 \mathrm{~h}$

(b) $\mathrm{MeOH}, \mathrm{rt}, 18 \mathrm{~h}$

(c) EDCl. $\mathrm{HCl}, \mathrm{DCM}, \mathrm{rt}, 15-18 \mathrm{~h}$

Scheme 11: Synthesis of the 5,5-ring system, imidazo[1,2-b]pyrazol-2-ones.

Scheme 12: Synthesis of 5-amino-3-(pyrrol-2-yl)pyrazole-4-carbonitrile.

Synthesis of 5-amino-3-aryl-1H-pyrazoles $\mathbf{5 3}$ has been reported using benzoylacetonitrile $\mathbf{5 1}$ as starting material. Substituted phenylhydrazines on reaction with substituted 1-aminocinnamonitriles 52, obtained from base catalyzed reaction of benzoylacetonitrile 51 and acetonitrile, yielded 5-amino-3-aryl-1H- 3-Iminobutyronitrile (55) couples with aromatic diazonium salts pyrazoles 53. Corresponding amide derivatives, i.e., $N-(1,3-\quad$ in a similar manner to yield 2-arylhydrazono-3-iminobutyroni-
diaryl-1H-pyrazol-5-yl)benzamides $\mathbf{5 4}$ were prepared by further treating aminopyrazoles $\mathbf{5 3}$ with substituted benzoyl chlorides in DCM (Scheme 13) [44].

= 2-Pyrrole, $\mathrm{C}_{2} \mathrm{H}_{5}$

$p-\mathrm{NO}_{2} \mathrm{C}_{6} \mathrm{H}_{4}$ 


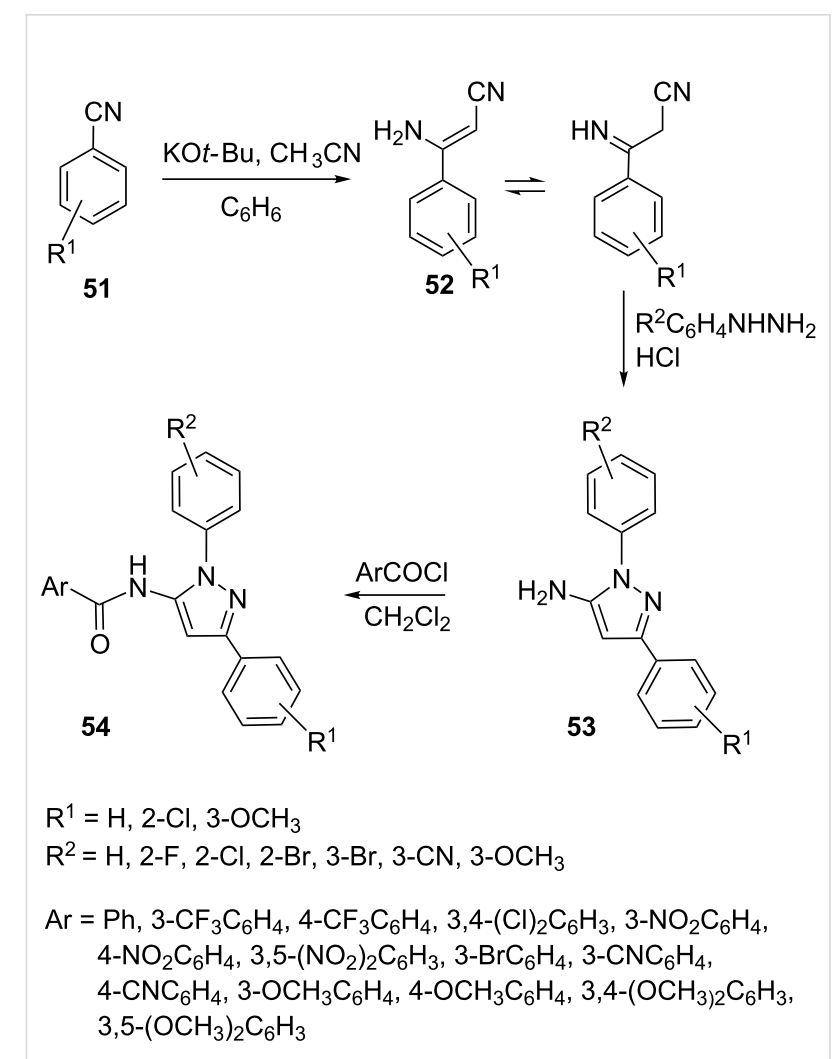

Scheme 13: Synthesis of $N$-(1,3-diaryl-1H-pyrazol-5-yl)benzamide.

triles 56. Treatment of hydrazones $\mathbf{5 6}$ with hydrazine hydrate in refluxing ethanol afforded the corresponding 5-amino-4arylazo-3-methylpyrazoles 57 in good yields [45]. Pyrazoles 57 further reacted with $\mathrm{N}$-aryl-2-oxo-2-phenylethanehydrazonoyl bromides 58 to yield 3,7-bis(arylazo)-6-methyl-2-phenyl-1 $H$ imidazo[1,2-b]pyrazoles 59 (Scheme 14).

\section{Reaction of malononitrile and its deriva- tives with hydrazines}

Malononitrile (60) and its derivatives have been shown to react smoothly with hydrazines to yield 3,5-diaminopyrazoles that possess a wide spectrum of biological activity. As early as in 1884, Rothenburg [46] reported the simplest reaction, i.e., the condensation of malononitrile with hydrazine to give 3,5diaminopyrazole (61) (Scheme 15).<smiles>N#CCC#[N+]N</smiles>

Scheme 15: Synthesis of 3,5-diaminopyrazole.

The work was subsequently reinvestigated by Sato [47] who found that instead of 3,5-diaminopyrazole, two other products were produced. These compounds were characterized as 5-amino-4-cyanopyrazole 64 and 5-amino-3-hydrazinopyrazole (65). It was suggested that the formation of $\mathbf{6 4}$ resulted when two moles of malononitrile condensed with one mole of hydrazine. In this reaction dimerization of malonitrile $\mathbf{6 2}$ occurs before the reaction with hydrazine to give $\mathbf{6 3}$. However, when one mole of malononitrile condenses with two moles of hydrazine, the formation of $\mathbf{6 5}$ takes place via the mechanistic pathway outlined in Scheme 16.

The reaction of substituted hydrazines with malononitrile follows a similar course to yield $\mathbf{6 7},[48,49]$ which is the 1 -substituted analog of $\mathbf{6 4}$ (Scheme 17). However, with substituted malononitriles 66 no such dimerization is possible and the

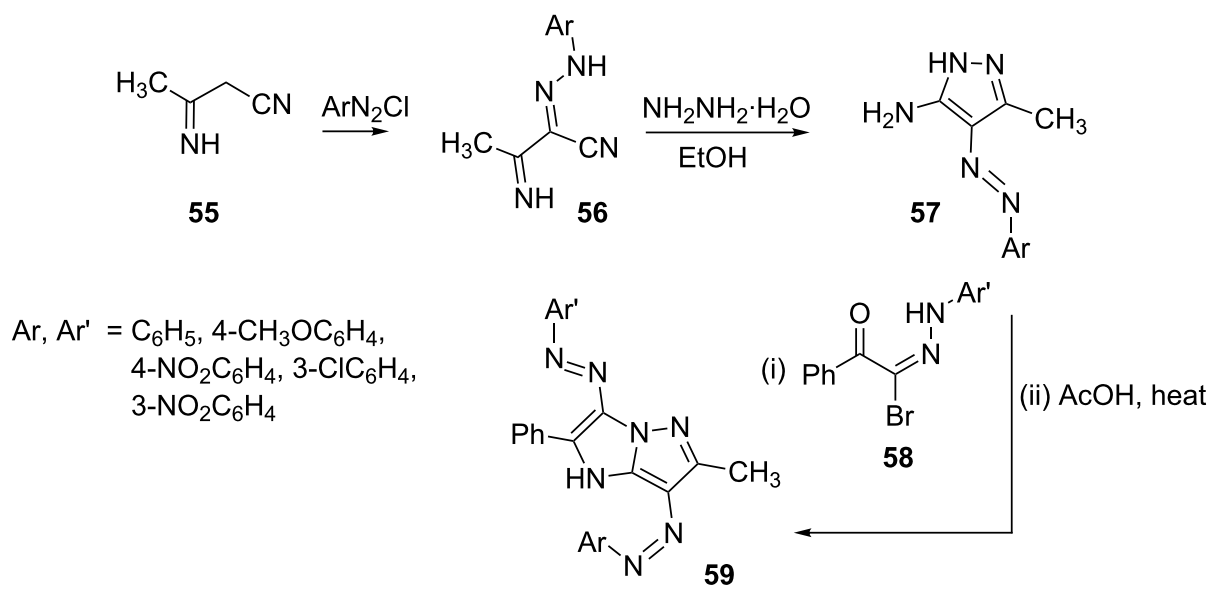




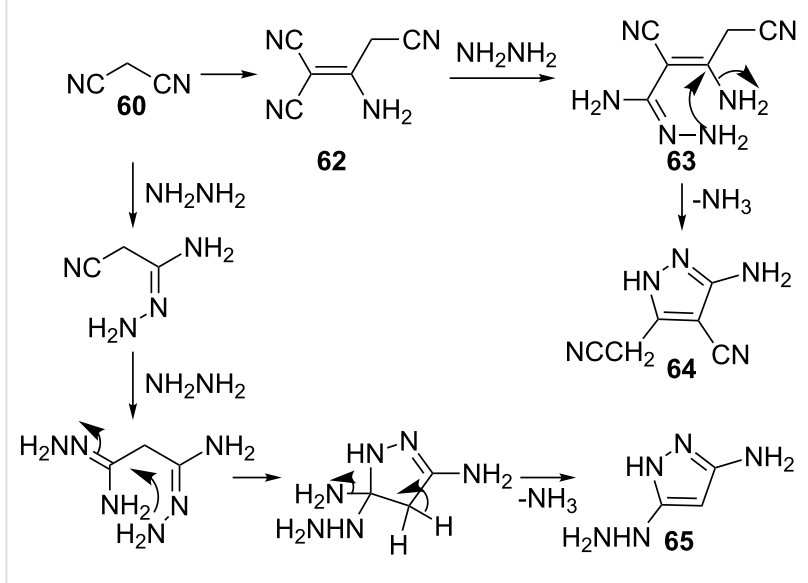

Scheme 16: Synthesis of 5-amino-4-cyanopyrazole and 5-amino-3hydrazinopyrazole.

condensation with hydrazine hydrate results in the smooth formation of 3,5-diaminopyrazoles 68 (Scheme 17) [50-53].

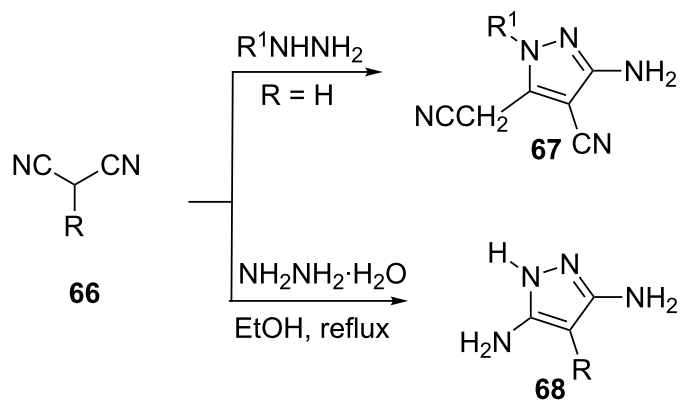

$\mathrm{R}=$ alkyl, aryl

Scheme 17: Synthesis of 3,5-diaminopyrazoles with substituted malononitriles.
Arulsamy and Bohle [54] have reported that the reaction of oximinomalononitrile (69) with hydrazine gives 3,5-diamino-4oximinopyrazole (70) as the sole product (Scheme 18).

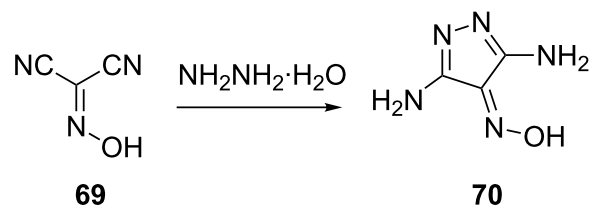

Scheme 18: Synthesis of 3,5-diamino-4-oximinopyrazole.

Shvekhgeimer and Ushakova [55] have reported the synthesis of 4-arylazo-3,5-diaminopyrazoles $\mathbf{7 3}$ starting from substituted sulfonamides 71. Sulfonamides $\mathbf{7 1}$ after diazotization undergo a coupling reaction with malononitrile to generate the hydrazones 72, which on cycloaddition with hydrazine hydrate give the corresponding pyrazoles (Scheme 19).

Reaction of ketenes, particularly those with a cyano group at one end and a leaving group such as alkoxy, alkylthio or halogen at the other, with hydrazine and its derivatives has assumed great importance in the synthesis of 5-aminopyrazoles $[56,57]$. The advantage of this procedure resides in the frequent possibility of forecasting the structure of the reaction product.

Cheng and Robins [58] have reported the synthesis of 5-amino4-cyanopyrazoles $\mathbf{7 6}$ by the reaction of hydrazines with alkoxymethylenemalononitriles 74a ( $\mathrm{Y}=$ OR', Scheme 20). Similar results were obtained when aminomethylenemalononitriles 74b ( $\mathrm{Y}=\mathrm{NHR}$ ') were treated with hydrazine indicating that reaction is initiated on the vinyl ether (vinylamine) group of $\mathbf{7 4 a} / \mathbf{b}$ to give 5-aminopyrazole-4-carbonitrile $\mathbf{7 6}$ through the intermediacy of 75 [59]. However, Elnagdi et al. [60] have reported that when ethyl hydrazinoacetate condenses with 74a or b, a change in regiochemistry occurs to yield 3-amino-4cyanopyrazoles 77 (Scheme 20).

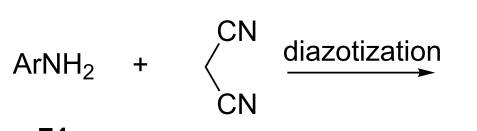

71<smiles>[R]NS(=O)(=O)c1ccc(I)cc1</smiles><smiles>[Y20]N/N=C(\[Al])C#N</smiles><smiles>[NH3+][NH3+]</smiles><smiles>Nc1n[nH]c(N)c1N=NBr</smiles><smiles>[R]C=[Bi]Br</smiles> 


$$
\begin{aligned}
& \text { (i) } \mathrm{NH}_{2} \mathrm{NH}_{2} \\
& \text { (ii) } \mathrm{RNHNH}_{2} \\
& \text { (iii) } \mathrm{C}_{2} \mathrm{H}_{5} \mathrm{CO}_{2} \mathrm{CH}_{2} \mathrm{NHNH}_{2} \\
& \mathrm{Y}=\mathrm{OR}^{\prime}(\mathbf{7 4 a}) \\
& =\mathrm{NHR}^{\prime} \text { (74b) } \\
& \mathrm{R}=\text { alkyl, aryl, heteroaryl } \\
& \mathrm{R} \text { ' = alkyl, aryl }
\end{aligned}
$$

Scheme 20: Synthesis of 3- or 5-amino-4-cyanopyrazoles.

Ethoxymethylenemalononitrile $\left(\mathrm{R}=\mathrm{OC}_{2} \mathrm{H}_{5}, \mathrm{R}^{1}=\mathrm{H}\right) \mathbf{7 4 c}$ and bis(methylthio)- methylenemalononitrile $\left(\mathrm{R}=\mathrm{R}^{1}=\mathrm{SCH}_{3}\right) \mathbf{7 4 d}$ on condensation with hydrazine hydrate yield 5-aminopyrazole4-carbonitrile $76\left(\mathrm{R}^{1}=\mathrm{H}\right)$ and 5-amino-3-methylthiopyrazole4-carbonitrile $76\left(\mathrm{R}^{1}=\mathrm{SCH}_{3}\right)$, respectively. These compounds were further treated with nitrous acid and coupled with different secondary amines to yield the triazenopyrazoles $\mathbf{7 8}$. Com- pounds 78 were tested for biological activity against HIV-1 and herpes simplex viruses, and showed moderate activity against HIV-1 virus (Scheme 21) [61,62].

An interesting synthesis of 5(3)-aminopyrazoles 81 and 82 [63] has been developed using thioacetals $\mathbf{7 9}$ and $\mathbf{8 0}$ of malononitrile, which are conveniently obtained by the reaction of aniline and diethyl phosphite with bis(methylthio)methylenemalononitrile 74d, respectively. Reaction with hydrazine monohydrate was thought to occur with loss of the methylthio group by nucleophilic attack of hydrazine and subsequent cyclization by attack on the cyano group (Scheme 22).

The synthesis of a few 3-substituted 5-amino-4-cyanopyrazoles 84 has recently been reported by the treatment of 1,1-dicyano-2methoxy-3-substituted propenes $\mathbf{8 3}$ with hydrazine hydrate in ethanolic TEA (Scheme 23) [64,65].

Acylated hydrazine, as expected, reacts with ethoxymethylenemalononitrile 74a in a similar manner. However, the reaction proceeds only in refluxing phosphorus oxychloride to produce compound 85 with a vinylated amino group (Scheme 24) [66].<smiles>[R]C([R])=C(C#N)C#N</smiles>

74c, d<smiles>[R]c1n[nH]c(N)c1C#N</smiles>

76<smiles>[R]N[R10][H]</smiles><smiles>[R]c1n[nH]c(/N=N/N([R])[R])c1C#N</smiles>

78

$$
\begin{aligned}
& \mathrm{R}=\mathrm{OEt}, \mathrm{R}_{1}=\mathrm{H}(\mathbf{7 4 c}) \\
& \mathrm{R}=\mathrm{R}^{1}=\mathrm{SCH}_{3}(\mathbf{7 4 d}) \quad \mathrm{R}^{2}, \mathrm{R}^{3}=\mathrm{Me}, \mathrm{Et}, \mathrm{Pr}, \mathrm{Ph}
\end{aligned}
$$

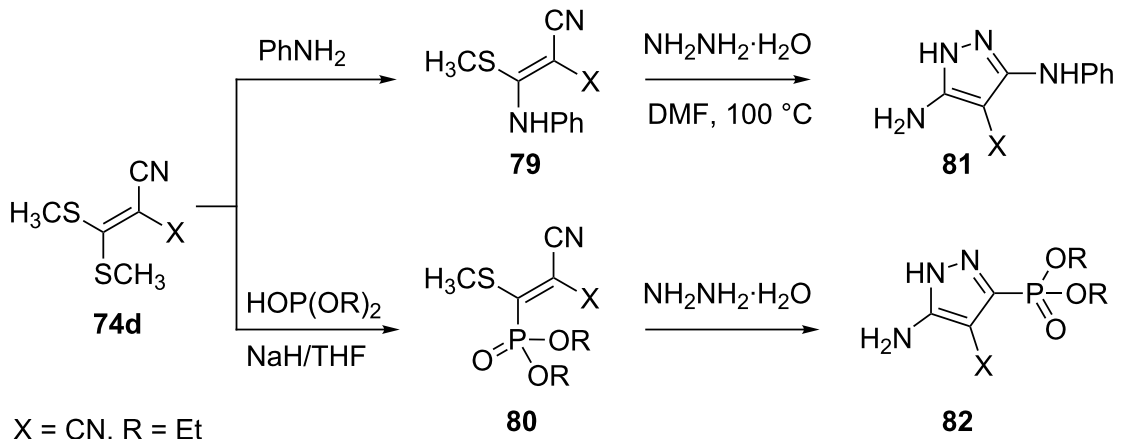

$\mathrm{X}=\mathrm{CN}, \mathrm{R}=\mathrm{Et}$

82

$\mathrm{X}=\mathrm{CN}, \mathrm{R}=i-\mathrm{Pr}$ 
<smiles>[R]C(OC)=C(C#N)C#N</smiles>

83<smiles>[R]c1n[nH]c(N)c1C#N</smiles>

84

$\mathrm{R}=i-\mathrm{Pr}, \mathrm{Ph}$, benzyl, $-\mathrm{CH}_{2}$ (1-naphthyl)

Scheme 23: Synthesis of 3-substituted 5-amino-4-cyanopyrazoles.<smiles>CCO/C=C(/C#N)C(=O)NNc1c(C#N)cnn1C(C)=O</smiles>

Scheme 24: Synthesis of 2-\{[(1-acetyl-4-cyano-1H-pyrazol-5yl)amino]methylene\}malononitrile.

Ketene dithioacetals $\mathbf{8 6}$ were utilized for the synthesis of corresponding pyrazole carbodithioates $\mathbf{8 8}$ by cyclization with methyl- or benzylhydrazine carbodithioate $\mathbf{8 7}$ in ethanolic TEA at room temperature. As before, the reaction proceeds via the nucleophilic substitution of the alkylthio group by the unsubstituted nitrogen of the hydrazine. The reaction of bis(methylthio)methylenecyanoacetamide $86\left(\mathrm{R}=\mathrm{CH}_{3}, \mathrm{X}=\mathrm{CONH}_{2}\right)$ with aromatic amines gave the corresponding 3-N-substituted aminoacrylamides $\mathbf{8 9}$, which on further treatment with phenylhydrazine furnished the corresponding 5-amino-3-arylamino-1phenylpyrazole-4-carboxamides 90 (Scheme 25) [67].<smiles>[R5]C([R5])=C([Y])[NH2+][Na]</smiles>

$$
\mathrm{X}=\mathrm{CN}, \mathrm{CONH}_{2}
$$$$
\mathrm{R}=\mathrm{CH}_{3} \text {, benzyl }
$$$$
\mathrm{R}^{1}=\mathrm{CH}_{3} \text {, benzyl }
$$<smiles>[R]C(=S)n1nc([R])c([Y])c1N</smiles>

$\mathrm{ArNH}_{2} \downarrow$ when $\mathrm{X}=\mathrm{CN}, \mathrm{R}=\mathrm{CH}_{3}$

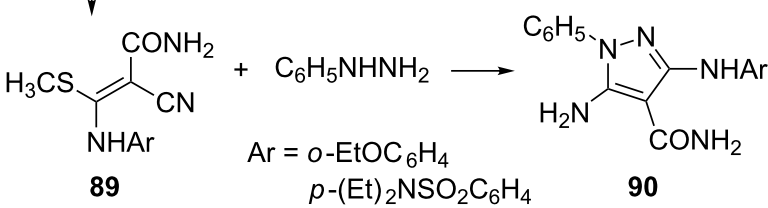

Scheme 25: Synthesis of 5-aminopyrazole carbodithioates and 5-amino-3-arylamino-1-phenylpyrazole-4-carboxamides.
Ketene $S, S$ - and $S, N$-acetals or tetracyanoethylene 91 on reaction with 3-hydrazino-6-( $p$-tolyl)pyridazine afforded the 5-amino-4-cyanopyrazoles 92 (Scheme 26) [68].<smiles>[R]/C([Hg])=C(\[R])C#N</smiles><smiles>Nc1ccccc1</smiles><smiles>[R]c1nn([Al])c(N)c1C#N</smiles>

$\mathrm{R}=\mathrm{R}^{1}=\mathrm{SCH}_{3}$

$\mathrm{R}=\mathrm{R}^{1}=\mathrm{CN}$

$\mathrm{R}=\mathrm{NHPh}, \mathrm{R}^{1}=\mathrm{SCH}_{3}$<smiles>[3H]c1ccc(-c2ccc(C)cc2)nn1</smiles>

Scheme 26: Synthesis of 5-amino-4-cyanopyrazoles.

Several thiazolylpyrazoles $\mathbf{9 7 - 1 0 0}$ bearing a variety of substituents at positions 3 and 4 were prepared by the condensation of 2-hydrazino-4-phenylthiazole (93) in presence of TEA with arylidenenitriles 94, cyclohexylidene malononitrile (95), ethyl dimethylthiomethylene cyanoacetate (96) and ethoxymethylenemalononitrile (74), respectively, (Scheme 27) [69].

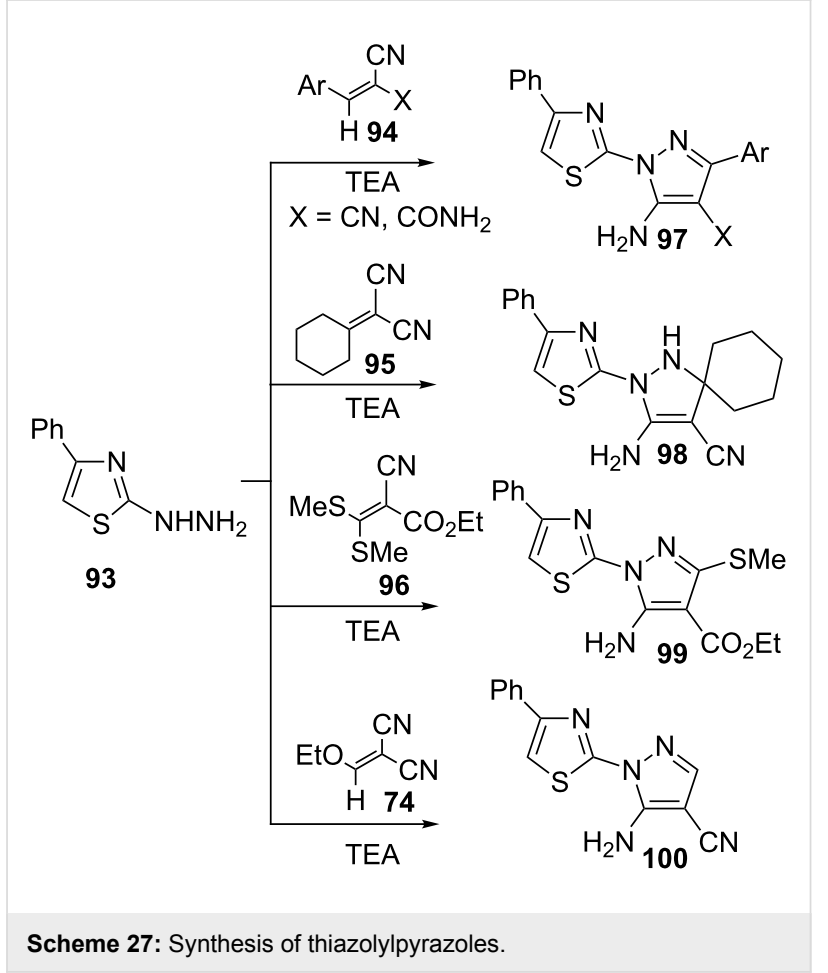

Synthesis of 5-amino-1-heteroaryl-3-methyl/aryl-4-cyanopyrazoles 102 has been carried out by us by treating various heteroarylhydrazines with alkylidenemalononitriles 101 in refluxing ethanol (Scheme 28) [70]. The starting material 101a ( $\mathrm{R}=\mathrm{C}_{2} \mathrm{H}_{5}, \mathrm{R}^{1}=\mathrm{CH}_{3}$ ) was obtained by the reaction of malononitrile with triethyl orthoacetate in acetic anhydride 


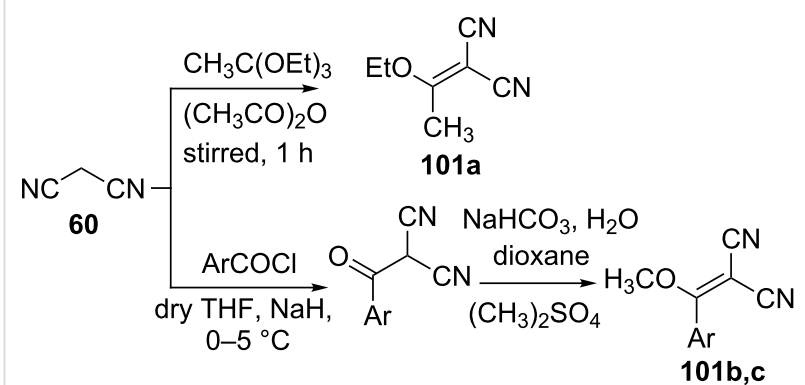<smiles>[R]C([R2])=C(C#N)C[NH2+][CH]NNc1ccco1</smiles>

$\mathrm{R}=\mathrm{Et}, \mathrm{R}^{1}=\mathrm{CH}_{3} \quad$ Het = benzothiazol-2-yl

$\mathrm{R}=\mathrm{CH}_{3}, \mathrm{R}^{1}=\mathrm{C}_{6} \mathrm{H}_{5} \quad$ 6-substituted benzothiazol-2-yl

$\mathrm{R}=\mathrm{CH}_{3}, \mathrm{R}^{1}=p-\mathrm{ClC}_{6} \mathrm{H}_{4} \quad$ 4-methylquinolin-2-yl

7-chloroquinolin-4-yl

Scheme 28: Synthesis of 5-amino-1-heteroaryl-3-methyl/aryl-4cyanopyrazoles.

whilst methoxyarylmethylidenemalonitriles $\mathbf{1 0 1 b}, \mathbf{c}$ were obtained via a two step procedure involving the aroylation of the malonitrile with aroyl chlorides in the presence of $\mathrm{NaH}$, followed by the treatment of the resulting intermediate with dimethyl sulfate.

Nilov et al. [71] have reported that the reaction of $\alpha$-cyano- $\beta$ dimethylaminocrotonamide (103) with hydrazine hydrate yields 5-amino-3-methylpyrazole-4-carboxamide (104). The reaction proceeds by loss of dimethylamine in first step followed by cyclization via nucleophilic attack on cyano group (Scheme 29).<smiles>C/C(=C(\C#N)C(N)=O)N(C)C</smiles>

103<smiles>Cc1n[nH]c(N)c1C(N)=O</smiles>

104
Scheme 29: Synthesis of 5-amino-3-methylpyrazole-4-carboxamide.

\section{Miscellaneous}

In addition to methods involving the reaction of hydrazine with $\beta$-ketonitriles, malononitrile and its derivatives, a number of other procedures have also been developed for the synthesis of 5 -aminopyrazoles. These methods are summarized below.

Synthesis of 4-acylamino-3(5)-amino-5(3)-arylsulfanylpyrazoles $\mathbf{1 0 7}$ by the reaction of 2-acylamino-3-arylsulfanyl-3chloroacrylonitriles $\mathbf{1 0 6}$ with hydrazine hydrate has been described. Compounds 106 were readily obtained from 105, the addition products of carboxylic acid amides and trichloroacetaldehyde, by the reaction sequence shown in the Scheme 30 [72].
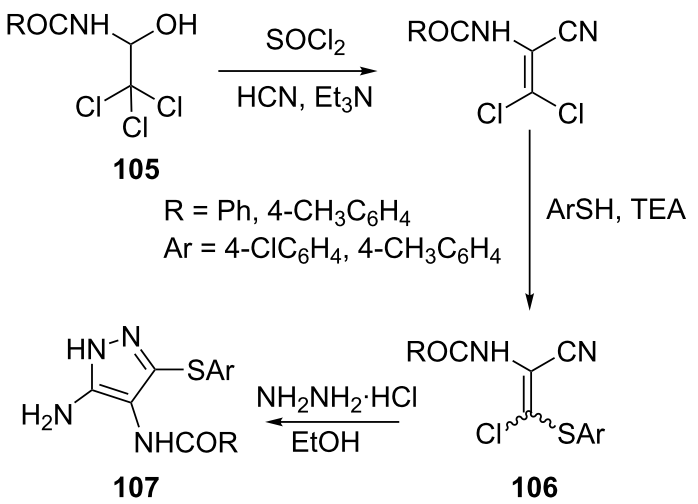

Scheme 30: Synthesis of 4-acylamino-3(5)-amino-5(3)-arylsulfanylpyrazoles.

The reaction of 2-chloro-2-chlorodifluoro/trifluoromethyl-1cyano-1-diethoxy phosphorylethylene 108 with arylhydrazines in refluxing carbon tetrachloride results in the rapid replacement of the chlorine atom with the terminal $\mathrm{NH}_{2}$ group of arylhydrazines to give intermediates $\mathbf{1 0 9}$, which is slowly transformed into 5-amino-1-aryl-4-diethoxyphosphoryl-3-halomethylpyrazoles 110. 2,6-Dichloro-4-trifluoromethylphenylhydrazine undergoes this reaction under more drastic conditions, i.e., prolonged refluxing $(16-20 \mathrm{~h})$ in carbon tetrachloride (Scheme 31) [73].

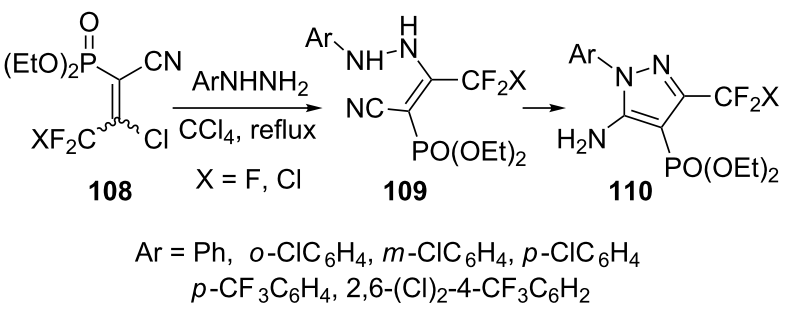

Scheme 31: Synthesis of 5-amino-1-aryl-4-diethoxyphosphoryl-3halomethylpyrazoles.

Heterocyclization reactions of trifluoromethylcyanovinyl phosphonates (TFMCPs) 111 with arylhydrazines have been studied: TFMCPs 111 can be used as precursors of 2,3-dihydro- $1 H$ pyrazoles 114 modified by both trifluoromethyl and diethoxyphosphoryl groups. Arylhydrazines add rapidly to the 
alkene double bond of $\mathbf{1 1 1}\left(\mathrm{X}=\mathrm{CF}_{3}\right)$ at room temperature to produce an adduct which slowly cyclizes to afford 2,3-dihydro$1 H$-pyrazoles 113 in good yields. 4-Trifluoromethylphenylhydrazine also adds to ethylene $\mathbf{1 1 1}\left(\mathrm{X}=\mathrm{CO}_{2} \mathrm{Et}\right)$, however, the resulting adduct $\mathbf{1 1 2}$ is formed primarily as a single diastereomer and does not undergo intramolecular cyclization to pyrazoline 113 even in refluxing benzene. Further, the reaction of isomeric alkene $\mathbf{1 1 5}$ with an arylhydrazine initially forms the unstable pyrazoline $\mathbf{1 1 6}$ that transforms into pyrazole $\mathbf{1 1 8}$. Firstly, the C-P bond apparently undergoes hydrolysis and the resulting 117 is slowly oxidized by atmospheric oxygen to yield pyrazole 118 (Scheme 32) [74].

Dodd et al. [75] have reported an efficient solid-support synthesis of 5-N-alkylamino and 5-N-arylaminopyrazoles $\mathbf{1 2 3}$. Heating the $\beta$-ketoesters 120 with resin-bound amines 119 in resin-compatible solvents, such as NMP or toluene, in the presence of DMAP gave the corresponding resin-immobilized $\beta$-ketoamides 121. The latter $\beta$-ketoamides 121, aryl- or alkylhydrazines and Lawesson's reagent were suspended in a mixture of THF/Py and heated at $50-55^{\circ} \mathrm{C}$ to afford resin-bound 5-aminopyrazoles 122. The free 5-aminopyrazoles $\mathbf{1 2 3}$ were liberated from the solid support by treatment with TFA (Scheme 33).

The reaction of cyanoacetylhydrazine (125) with $\alpha$-bromoacetophenone (124) gave the $N$-[2-bromo-1-phenylethylidene]-2cyanoacetohydrazide (126). Compound 126 readily underwent cyclization when treated with potassium cyanide to give 5-amino-1-cyanoacetyl-3-phenyl-1 $H$-pyrazole (128) through the intermediacy of the acyclic cyano derivative 127 (Scheme 34) [76].

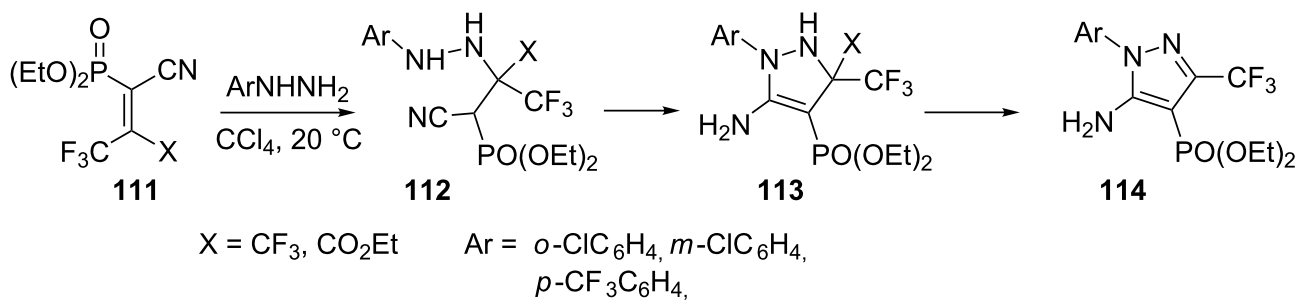

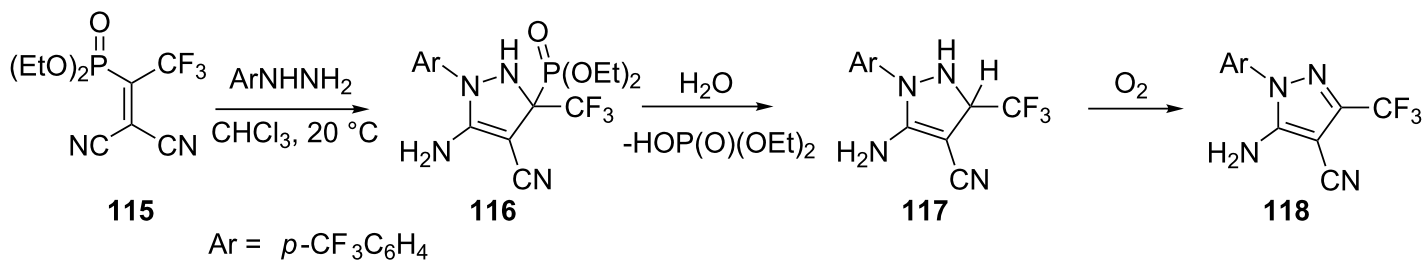<smiles>[R]NCc1ccc(O[O-])cc1OC</smiles>

119<smiles>[R]C(=O)C([R])C(=O)OC(C)(C)C</smiles>

120
DMAP (0.1 equiv) NMP, $85^{\circ} \mathrm{C}, 10-24 \mathrm{~h}$

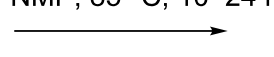

121

$\mathrm{R}^{4} \mathrm{NHNH}_{2}$ ( 2.5 equiv) Lawesson's reagent ( 2.5 equiv) THF/Py $(95 / 5), 55^{\circ} \mathrm{C}, 40 \mathrm{~h}$

$$
\begin{aligned}
& \mathrm{R}^{1}=\mathrm{Bn}, \mathrm{Ph} \\
& \mathrm{R}^{2}=\mathrm{H}, \mathrm{CH}_{3} \\
& \mathrm{R}^{3}=\mathrm{CH}_{3}, \mathrm{Ph} \\
& \mathrm{R}^{4}=\mathrm{Bn}, \mathrm{Ph}
\end{aligned}
$$

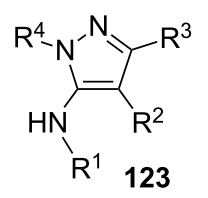

$25 \%$ TFA/DCE $\mathrm{rt}, 1 \mathrm{~h}$ 
<smiles>N#CCC(=O)NN=C(CBr)c1ccccc1</smiles>

Scheme 34: Synthesis of 5-amino-1-cyanoacetyl-3-phenyl-1H-pyrazole.

Hydrazonoyl chlorides 129 on treatment with benzothiazole-2acetonitrile in ethanolic sodium ethoxide solution at room temperature afforded intermediate hydrazones $\mathbf{1 3 0}$ which on cyclization gave products identified as 3-substituted 5-amino-1aryl-4-(benzothiazol-2-yl)pyrazoles 131 (Scheme 35) [77].

Similarly, hydrazonyl chloride $\mathbf{1 3 2}$ on treatment with ethyl cyanoacetate in $\mathrm{NaH} / \mathrm{DMF}$ at $0{ }^{\circ} \mathrm{C}$ gave intermediate $\mathbf{1 3 3}$ which underwent cyclization to afford 5-amino-4-carbethoxy-3methyl-1-(4-sulfamoylphenyl)pyrazole 134 (Scheme 36) [78].

The synthetic precursor $\mathbf{1 3 6}$ for preparation of 5-aminopyrazole 137 was obtained as the major product from the acidic cyclization of the hydrazine with enol $135(\mathrm{R}=\mathrm{H})$. By contrast, cyclization of the hydrazine with methyl ether $\mathbf{1 3 5}(\mathrm{R}=\mathrm{Me})$ under basic conditions, completely reverts the regioselectivity of this reaction and the 3-aminopyrazole intermediate $\mathbf{1 3 6}$ was obtained in excellent yield (93\%) as a single isomer. The new derivatives 137 were shown to inhibit intracellular phosphorylation of hsp27 as well as LPS-induced TNFa release in cells (Scheme 37) [79].

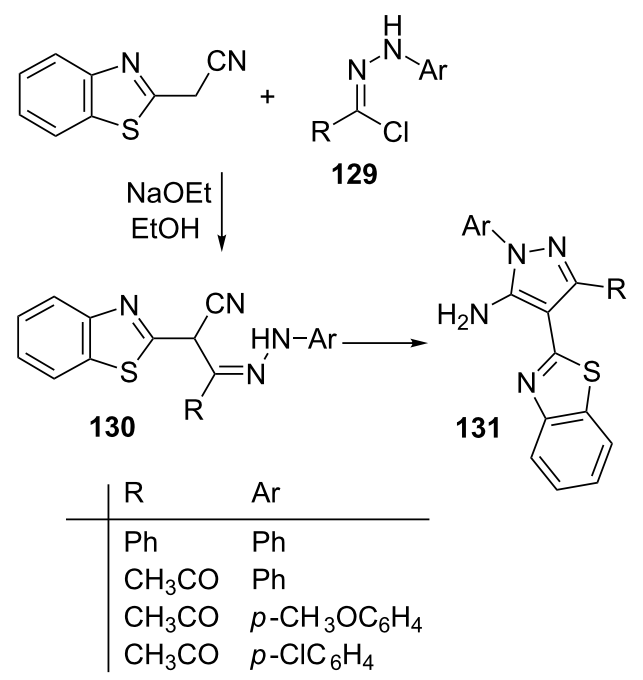

Scheme 35: Synthesis of 3-substituted 5-amino-1-aryl-4-(benzothiazol-2-yl)pyrazoles.

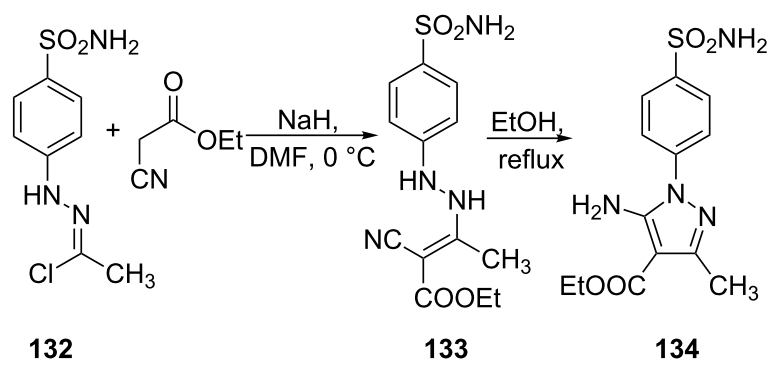

Scheme 36: Synthesis of 5-amino-4-carbethoxy-3-methyl-1-(4sulfamoylphenyl)pyrazole.

The potassium salt of ethyl cyanopyruvate $\mathbf{1 3 8}$ on reaction with methyl carbazate $\mathbf{1 3 9}$ in a mixture of chloroform and ethyl acetate, saturated with hydrogen chloride resulted in situ protonation of the potassium salt followed by formation of intermedi-<smiles>[R]O/C=C(\C#N)c1ccc(C#N)cc1</smiles>

135

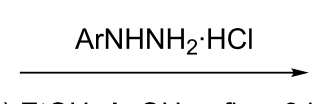

(a) $\mathrm{EtOH}, \mathrm{AcOH}$, reflux, $3 \mathrm{~h}$

(b) $\mathrm{NaOEt} / \mathrm{EtOH}$, reflux, $4 \mathrm{~h}$

$\mathrm{Ar}=p-\mathrm{CH}_{3} \mathrm{OC}_{6} \mathrm{H}_{4}$

for (a), $\mathrm{R}=\mathrm{H}, \mathrm{X}=\mathrm{NH}_{2}, \mathrm{Y}=\mathrm{H}$

for (b), $\mathrm{R}=\mathrm{Me}, \mathrm{Y}=\mathrm{NH}_{2}, \mathrm{X}=\mathrm{H}$<smiles>[Y]c1nn([Ga])c([X])c1-c1ccc(C#N)cc1</smiles>

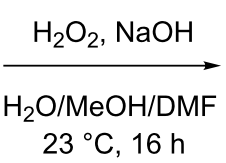

136<smiles>[X]c1nn([Ga])c([X])c1-c1ccc(C(N)=O)cc1</smiles>

137 


$$
\begin{aligned}
& \text { (i) } \mathrm{CHCl}_{3} \text { /ethyl acetate, } \mathrm{HCl} \text { satd, rt; } \\
& \text { (ii) } \mathrm{CH}_{3} \mathrm{CN}, \mathrm{TEA}, \mathrm{rt} \text {; } \\
& \text { (iii) } \mathrm{Fmoc}-\mathrm{Gly}-\mathrm{Cl}, \mathrm{THF}, 70{ }^{\circ} \mathrm{C} \text {; } \\
& \text { (iv) } 20 \% \text { piperidine, DMF. }
\end{aligned}
$$<smiles></smiles>

Scheme 38: Synthesis of the diglycylpyrazole 142.

ate hydrazone. Further treatment with TEA in acetonitrile resulted in cyclization and furnished the new 5-aminopyrazole acid ester 140. Reaction of $\mathbf{1 4 0}$ with the acid chloride of (9-fluoroenylmethyl)carbamate(Fmoc)-protected glycine led to peptide coupling and subsequent Fmoc deprotection with piperidine gave 141. A second coupling step can also be performed with Fmoc-protected glycine acid chloride, which affords, again after Fmoc removal, the diglycylpyrazole 142 (Scheme 38) [80].

A new synthetic route [81] to 5-amino-1-aryl-4-benzoyl pyrazole derivatives 144 involves the reaction of $\beta$-ketonitriles with $N, N$ '-diphenylformamidine to give initially the cyclocondensation precursors 143 which is then transformed to 144 by reaction with hydrazines (Scheme 39).

The enamine nitrile 145 reacts readily with 3-hydrazinopropanenitrile to yield $\mathbf{1 4 6}$ via elimination of chloroform by the attack of less hindered nitrogen of reagent. Cyclization by treatment of the latter with $3 \% \mathrm{NaOH}$ solution gave 4-benzoyl-3,5diamino-1-(2-cyanoethyl)pyrazole 147 (Scheme 40) [82].

2-Cyano- $\mathrm{N}$-(1,5-dimethyl-3-oxo-2-phenyl-2,3-dihydro- $1 \mathrm{H}$ pyrazol-4-yl)acetamide (148) was utilized for the synthesis of the 5-aminopyrazole $\mathbf{1 5 0}$. Treatment of $\mathbf{1 4 8}$ with phenyl isothiocyanate in DMF in the presence of potassium hydroxide at room temperature, followed by treatment with methyl iodide afforded<smiles>[R]c1cccc(C(=O)CCl)c1</smiles><smiles>[R]c1cccc(C(=O)/C(C#N)=C/Nc2ccccc2)c1</smiles>

$\mathrm{R}=\mathrm{H}, \mathrm{OMe}$

$\mathrm{R}^{1}=\begin{array}{r}\mathrm{H}, \mathrm{Me}, t-\mathrm{Bu}, \mathrm{Ph}, 4-\mathrm{FC}_{6} \mathrm{H}_{4}, 2-\mathrm{FC}_{6} \mathrm{H}_{4}, \\ 4-\mathrm{NO}_{2} \mathrm{C}_{6} \mathrm{H}_{4}, 4-\mathrm{MeOC}_{6} \mathrm{H}_{4}, 4-\mathrm{MeC}_{6} \mathrm{H}_{4}\end{array} \mid \mathrm{R}^{1} \mathrm{NHNH}_{2}$<smiles>[R]c1cccc(C(=O)c2cnn([R])c2N)c1</smiles>

Scheme 39: Synthesis of 5-amino-1-aryl-4-benzoylpyrazole derivatives.

the novel ketene $N, S$-acetal 149. Reaction of 149 with hydrazine in refluxing ethanol gave the corresponding 5-aminopyrazole derivative 150. The reaction proceeds in the usual manner, i.e., loss of methylthio group by nucleophilic attack of hydrazine in the first step followed by the cyclization (Scheme 41) [83].

Hutaud et al. [84] have reported a unique method for the preparation of 3,5-diaminopyrazoles $\mathbf{1 5 3}$ in good yields by the treatment of the enamine nitrile $\mathbf{1 5 1}$ with trifluoroacetic acid. Boc<smiles>N#CC(CNCCN)=C(N)C(Cl)(Cl)Cl</smiles>

145

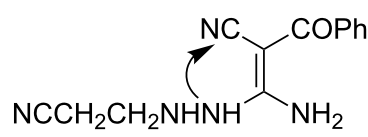

146
$3 \% \mathrm{NaOH}$<smiles>N#CCCn1nc(N)c(C(=O)c2ccccc2)c1N</smiles> 


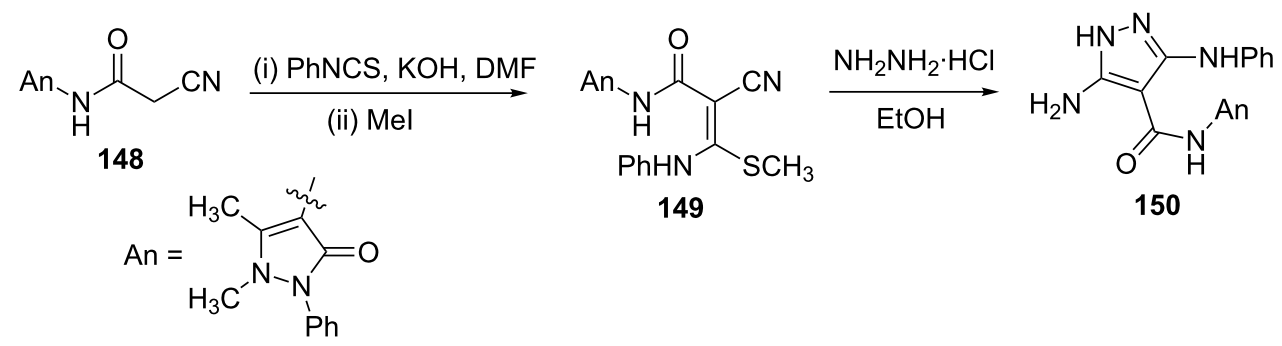

Scheme 41: Synthesis of the 5-aminopyrazole derivative 150.

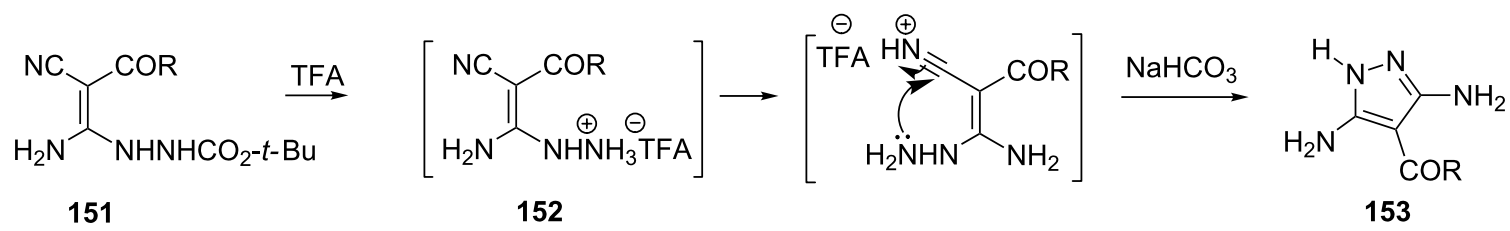

$\mathrm{R}=p-\mathrm{CH}_{3} \mathrm{C}_{6} \mathrm{H}_{4}, p-\mathrm{ClC}_{6} \mathrm{H}_{4}$

Scheme 42: Synthesis of 3,5-diaminopyrazoles 153.

deprotection by trifluoroacetic acid to $\mathbf{1 5 2}$ is followed by spontaneously nucleophilic attack on the cyano group by the $\mathrm{N}$-terminal nitrogen of the hydrazine substitutent (Scheme 42).

Beam et al. [85] have reported a novel synthesis of 5-aminopyrazoles 155 from polylithiated $C(\alpha), N$-thiosemicarbazones $(\mathrm{X}=$ $\mathrm{S})$ or $C(\alpha), N$-semicarbazones $(\mathrm{X}=\mathrm{O})$. The polylithiated intermediates, prepared from $C(\alpha), N$-thiosemicarbazones $(\mathrm{X}=\mathrm{S})$ or $C(\alpha), N$-semicarbazones $(\mathrm{X}=\mathrm{O}) \mathbf{1 5 4}$ and an excess of lithium diisopropylamide (LDA), underwent cyclization and on subsequent hydrolysis gave the 5-aminopyrazole derivatives 155 (Scheme 43).

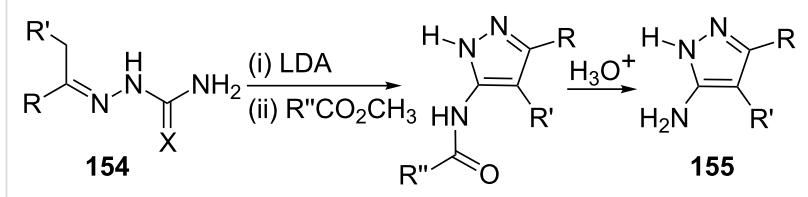

$X=O$ or $S, R=P h, R^{\prime}=H, R^{\prime \prime}=H$

$X=S, R=4-F_{6} H_{4}, R^{\prime}=H, R^{\prime \prime}=4-(2-$ phenylquinolyl)

$X=S, R=2-$ naphthyl, $R^{\prime}=H, R^{\prime \prime}=3-\mathrm{ClC}_{6} \mathrm{H}_{4}$

$\mathrm{X}=\mathrm{O}, \mathrm{R}=\mathrm{Ph}, \mathrm{R}^{\prime}=\mathrm{CH}_{3}, \mathrm{R}^{\prime \prime}=5-\mathrm{Cl}-2-\mathrm{HOC}_{6} \mathrm{H}_{3}$

$\mathrm{X}=\mathrm{O}, \mathrm{R}=\mathrm{R}^{\prime}=-\left(\mathrm{CH}_{2}\right)_{5^{-}}, \mathrm{R}^{\prime \prime}=4-(2-$ phenylquinolyl)

Scheme 43: Synthesis of 5-aminopyrazoles derivatives 155 via lithiated intermediates.
It has been reported that 1,2,4-oxadiazolylmethylenedioxolanes 156 undergo cyclization on treatment with 2-hydroxyethylhydrazine to give 5-amino-4-(1,2,4-oxadiazol-5-yl)-pyrazoles [86] 157 (Scheme 44).

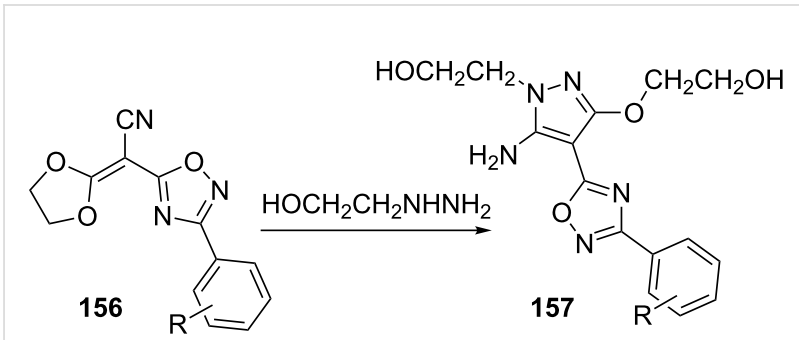

Scheme 44: Synthesis of 5-amino-4-(1,2,4-oxadiazol-5-yl)-pyrazoles 157.

The reaction of 3-aminothioacrylamide $\mathbf{1 5 8}$ with hydrazine hydrochloride has been reported to furnish the 5-aminopyrazole 159 in good yield. Various derivatives were tested for anticonvulsant activity in a variety of test models (Scheme 45) [87].

Another interesting synthesis that affords tetrasubstituted 5-aminopyrazole derivatives $\mathbf{1 6 2}$ involves the reaction of $\mathrm{N}, \mathrm{N}$ disubstituted hydrazines 160 with ketones [88]. The hydrazones 161 so formed undergo cyclization in the presence of base to yield the desired compounds 162 (Scheme 46). 
<smiles>S=C(C=CN1CCOCC1)c1ccc(Cl)cc1</smiles>
158<smiles>CCOC(N)(N)Cl</smiles>

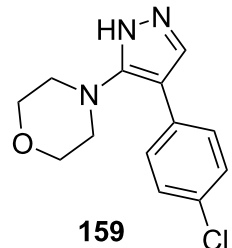

159
Scheme 45: Synthesis of a 5-aminopyrazole with anticonvulsan activity.

$$
\mathrm{R}=\mathrm{H}, \mathrm{CO}_{2} \mathrm{Et}
$$

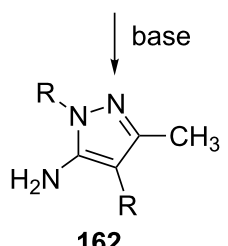

Scheme 46: Synthesis of tetrasubstituted 5-aminopyrazole derivatives.

Abdelhamid et al. [89,90] have reported the synthesis of substituted 5-aminopyrazoles $\mathbf{1 6 4}$ by the treatment of active methylene compounds such as malononitrile, ethyl cyanoacetate etc. with hydrazonoyl halides $\mathbf{1 6 3}$ in ethanolic sodium ethoxide (Scheme 47).

$$
\begin{aligned}
& \mathrm{Z}=\mathrm{CN}, \mathrm{CO}_{2} \mathrm{Et} \\
& \mathrm{X}=\mathrm{Cl} \text { or Br} \\
& \mathrm{Ar}=p-\mathrm{ClC}_{6} \mathrm{H}_{4}
\end{aligned}
$$

Scheme 47: Synthesis of substituted 5-aminopyrazoles from hydrazonoyl halides.

Ioannidou and Koutentis [91] investigated the conversion of isothiazoles into pyrazoles on treatment with hydrazine. The influence of various C-3, C-4 and C-5 isothiazole substituents and some limitations of this ring transformation were investigated. When a good nucleofugal group (e.g., $\mathrm{Cl}, \mathrm{Br}$ and $\mathrm{I}$ ) is present at $\mathrm{C}-3$ in the isothiazole $\mathbf{1 6 5}$, it is replaced by an amino group and 5-aminopyrazoles 166 are obtained. However, when the 3-substituent is not a good leaving group it is retained in the pyrazole product 167. A series of 3-chloro-5-substituted isothiazole-4-carbonitriles 168 bearing steric and/or electronic constraints at C-5 were also treated with anhydrous hydrazine and the corresponding 3-aminopyrazoles 169 were obtained in varying yields. However, when the substituent at C-5 in isothiazole was a better nucleofuge (e.g., $\mathrm{PhO}, \mathrm{PhS}$ and $\mathrm{Cl}$ ), the 5 -hydrazinoisothiazole $\mathbf{1 7 0}$ was rapidly produced in good yield. Several isothiazoles $\mathbf{1 7 1}$ with a variety of C-4 substituents were also reacted with anhydrous hydrazine to yield the corresponding 3-amino-5-phenylpyrazoles $\mathbf{1 7 2}$. Reaction time and the yield of the reaction was dependent on the substituents present (Scheme 48).
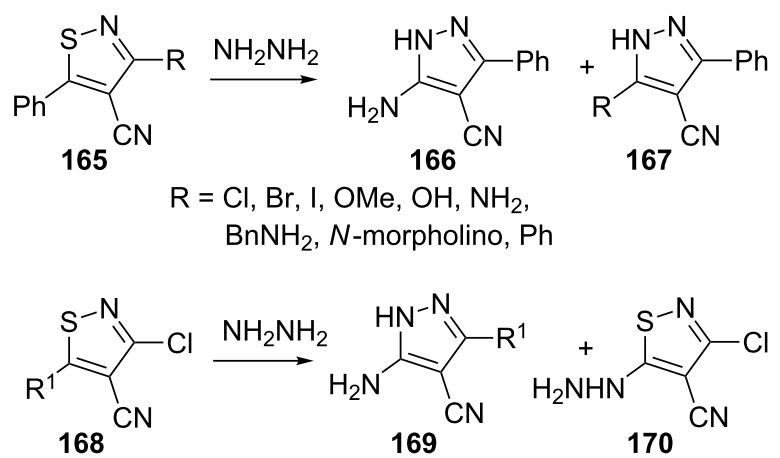

$\mathrm{R}^{1}=$ aryl, 3-thienyl, $\mathrm{NH}_{2}, \mathrm{NHNH}_{2}, \mathrm{BnNH}_{2}$, $\mathrm{N}$-morpholino, $\mathrm{PhNH}, \mathrm{OMe}, \mathrm{PhO}, \mathrm{PhS}, \mathrm{Cl}$

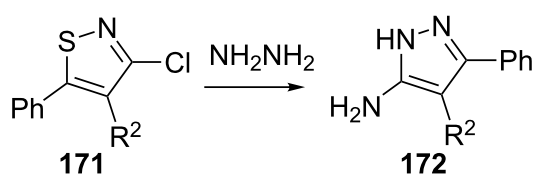

$\mathrm{R}^{2}=\mathrm{CN}, \mathrm{H}, \mathrm{Br}, \mathrm{NH}_{2}, \mathrm{Ph}$

Scheme 48: Synthesis of 3-amino-5-phenylpyrazoles from isothiazoles.

The reaction of hydroxylamine with 3-(4-phenyl-1,2,4-triazol3-yl)chromones $\mathbf{1 7 3}$ has been reported to give the 2-aminochromones 174. The 2-aminochromones 174 undergo ring transformation to afford the 5-aminopyrazoles 175 but only upon prolonged heating with hydrazine hydrate in high boiling alcohols (2-propanol, butanol) or in DMF (Scheme 49) [92].

\section{Conclusion}

5-Aminopyrazole is an important heterocyclic system which has great significance in pharmaceutical industry as well as being a useful synthon for the synthesis of many bridgehead heterocycles. This review describes new strategies and the development of novel concepts along with conventional methods to 


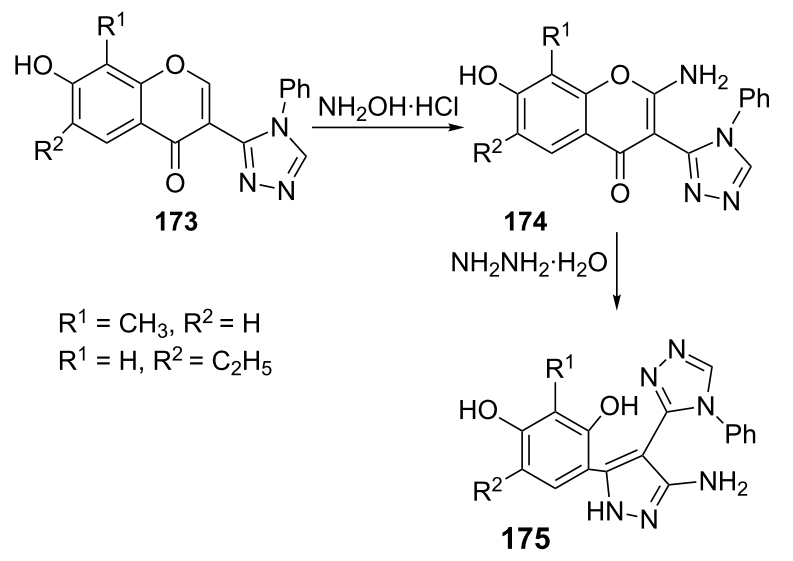

Scheme 49: Synthesis of 5-aminopyrazoles via ring transformation.

synthesize a wide variety of substituted 5-aminopyrazoles. Conventional methods such as condensation of $\beta$-ketonitriles, malononitrile and its derivatives with hydrazines in addition to modern methods of resin supported solid-phase synthesis, multi-component synthesis and ring transformations provide useful synthetic routes to 5-aminopyrazoles.

\section{Acknowledgements}

We thank the Council of Scientific and Industrial Research, New Delhi for the financial assistance to Rajiv Kumar.

\section{References}

1. Elguero, J. In Comprehensive Heterocyclic Chemistry; Katritzky, A. R.; Rees, C. W., Eds.; Pergamon Press: Oxford, 1984; Vol. 5, pp 167-303. doi:10.1016/B978-008096519-2.00072-2

2. Elguero, J. In Comprehensive Heterocyclic Chemistry II; Katritzky, A. R.; Rees, C. W.; Scriven, E. F. V., Eds.; Pergamon Press: Oxford, 1996; Vol. 3, pp 1-75. doi:10.1016/B978-008096518-5.00059-9

3. Kost, A. N.; Grandberg, I. I. In Advances in Heterocyclic Chemistry; Katritzky, A. R.; Boulton, A. J., Eds.; Academic Press: New York, 1966; Vol. 6, pp $347 \mathrm{ff}$.

4. Lee, K. Y.; Kim, J. M.; Kim, J. N. Tetrahedron Lett. 2003, 44, 6737-6740. doi:10.1016/S0040-4039(03)01648-4

5. Wiley, R. H.; Wiley, P. Pyrazolones, Pyrazolidones and Derivatives; John Wiley and Sons: New York, 1964

6. Behr, L. C.; Fusco, R.; Jarboe, C. H. In The Chemistry of Heterocyclic Compounds, Pyrazoles, Pyrazolines, Pyrazolidines, Indazoles and Condensed Rings; Weissberger, A., Ed.; Interscience Publishers: New York, 1967.

7. David, D. P.; Martin, D. J.; Charles, M. D. F. 5-Aminopyrazoles useful as selective inhibitors of the protein tyrosine kinase P56ick. WO 9740019 (A1), Nov 30, 1997.

8. Kordik, C. P.; Luo, C.; Zanoni, B. C.; Lovenberg, T. W.; Wilson, S. J.; Vaidya, A. H.; Crooke, J. J.; Rosenthal, D. I.; Reitz, A. B.

Bioorg. Med. Chem. Lett. 2001, 11, 2287-2290. doi:10.1016/S0960-894X(01)00449-8
9. Nakazato, A.; Okuyama, S. Drugs Future 1999, 24, 1089-1098. doi:10.1358/dof.1999.024.10.665576

10. Meegalla, S. K.; Doller, D.; Sha, D.; Soll, R.; Wisnewski, N.; Silver, G. M.; Dhanoa, D. Bioorg. Med. Chem. Lett. 2004, 14, 4949-4953. doi:10.1016/j.bmcl.2004.07.033

11. Huppatz, J. L. Aust. J. Chem. 1985, 38, 221-230. doi:10.1071/CH9850221

12. Shamroukh, A. H.; Rashad, A. E.; Sayed, H. H. Phosphorus, Sulfur Silicon Relat. Elem. 2005, 180, 2347-2360. doi:10.1080/104265090921074

13. Carter, T. A.; Wodicka, L. M.; Shah, N. P.; Velasco, A. M.; Fabian, M. A.; Treiber, D. K.; Milanov, Z. V.; Atteridge, C. E.; Biggs, W. H.; Edeen, P. T.; Floyd, M.; Ford, J. M.; Grotzfeld, R. M.; Herrgard, S.; Insko, D. E.; Mehta, S. A.; Patel, H. K.; Pao, W.; Sawyers, C. L.; Varmus, H.; Zarrinkar, P. P.; Lockhart, D. J. Proc. Natl. Acad. Sci. U. S. A. 2005, 102, 11011-11016. doi:10.1073/pnas.0504952102

14. An, H.; Eum, S.-J.; Koh, M.; Lee, S. K.; Park, S. B. J. Org. Chem. 2008, 73, 1752-1761. doi:10.1021/jo702196f

15. Abu Elmaati, T. M.; El-Taweel, F. M. J. Heterocycl. Chem. 2004, 41, 109-134. doi:10.1002/jhet.5570410201

16. Selleri, S.; Gratteri, P.; Costagli, C.; Bonaccini, C.; Costanzo, A.; Melani, F.; Guerrini, G.; Ciciani, G.; Costa, B.; Spinetti, F.; Martini, C.; Bruni, F. Bioorg. Med. Chem. 2005, 13, 4821-4834. doi:10.1016/j.bmc.2005.05.015

17. Gopalsamy, A.; Yang, H.; Ellingboe, J. W.; Tsou, H.-R.; Zhang, N.; Honores, E.; Powell, D.; Miranda, M.; McGinnis, J. P.; Rabindran, S. K. Bioorg. Med. Chem. Lett. 2005, 15, 1591-1594. doi:10.1016/j.bmcl.2005.01.066

18. Zhang, X.-Y.; Li, X.-Y.; Fan, X.-S.; Wang, X.; Qu, G.-R.; Wang, J.-J. Heterocycles 2009, 78, 923-936. doi:10.3987/COM-08-11561

19. Elnagdi, M. H.; Elgemeie, G. E. H.; Abd-Elaal, F. A.-E. Heterocycles 1985, 23, 3121-3153. doi:10.3987/R-1985-12-3121

20. Bagley, M. C.; Davis, T.; Dix, M. C.; Widdowson, C. S.; Kipling, D. Org. Biomol. Chem. 2006, 4, 4158-4164. doi:10.1039/b611493h

21. Butler, D. E.; Alexander, S. M. J. Heterocycl. Chem. 1982, 19, 1173-1177. doi:10.1002/jhet.5570190537

22. Elnagdi, M. H.; Elfahham, H. A.; Elgemeie, G. E. H. Heterocycles 1983 20, 519-550. doi:10.3987/R-1983-03-0519

23. Elnagdi, M. H.; Elmoghayar, M. R. H.; Elgemeie, G. E. H. Synthesis 1984, 1-26. doi:10.1055/s-1984-30717

24. Sunder, S.; Peet, N. P. J. Heterocycl. Chem. 1980, 17, 1527-1529. doi:10.1002/jhet.5570170734

25. Elderfield, R. C., Ed. Heterocyclic Compounds; John Wiley and Sons: New York, 1957; Vol. 5.

26. Snyder, H. R., Jr. J. Heterocycl. Chem. 1975, 12, 1303-1304. doi:10.1002/jhet.5570120640

27. Senga, K.; Robins, R. K.; Brien, D. E. J. Heterocycl. Chem. 1975, 12 , 899-901. doi:10.1002/jhet.5570120517

28. Joshi, K. C.; Pathak, V. N.; Garg, U. J. Heterocycl. Chem. 1979, 16, 1141-1145. doi:10.1002/jhet.5570160611

29. Singh, S. P.; Prakash, O.; Tomar, R. K.; Sawhney, S. N. Indian J. Chem. 1978, 16B, 733-735.

30. Singh, S. P.; Tomar, R. K.; Prakash, O.; Sawhney, S. N. Indian J. Chem. 1979, 17B, 372-374.

31. Smith, P. A. S.; Ahmad, Y. J. Org. Chem. 1971, 36, 2972-2974. doi:10.1021/jo00819a014

32. Kumar, V.; Aggarwal, R.; Tyagi, P.; Singh, S. P. Eur. J. Med. Chem. 2005, 40, 922-927. doi:10.1016/j.ejmech.2005.03.021 
33. Sosnovskikh, V. Y.; Sizon, A. Y.; Usachev, B. I. Russ. Chem. Bull. 2002, 51, 1270-1279. doi:10.1023/A:1020908831426

34. Aggarwal, R.; Kumar, V.; Tyagi, P.; Singh, S. P. Bioorg. Med. Chem. 2005, 14, 1785-1791. doi:10.1016/j.bmc.2005.10.026

35. Jachak, M.; Krießmann, U.; Mittelbach, M.; Junek, H. Monatsh. Chem. 1993, 124, 199-207. doi:10.1007/BF00808679

36. Kordik, C. P.; Luo, C.; Zanoni, B. C.; Dax, S. L.; McNally, J. J.; Lovenberg, T. W.; Wilson, S. J.; Reitz, A. B. Bioorg. Med. Chem. Lett 2001, 11, 2283-2286. doi:10.1016/S0960-894X(01)00448-6

37. Baraldi, P. G.; El-Kashef, H.; Manfredini, S.; de las Infantas, M. J. P.; Romagnoli, R.; Spalluto, G. Synthesis 1998, 1331-1334. doi:10.1055/s-1998-6095

38. Watson, S. P.; Wilson, R. D.; Judd, D. B.; Richards, S. A. Tetrahedron Lett. 1997, 38, 9065-9068. doi:10.1016/S0040-4039(97)10436-1

39. Wilson, R. D.; Watson, S. P.; Richards, S. A. Tetrahedron Lett. 1998 , 39, 2827-2830. doi:10.1016/S0040-4039(98)00257-3

40. Ma, W.; Peterson, B.; Kelson, A.; Laborde, E. J. Comb. Chem. 2009, 11, 697-703. doi:10.1021/cc900045t

41. Gao, Y.; Lam, Y. J. Comb. Chem. 2010, 12, 69-74. doi:10.1021/cc900063y

42. Blass, B. E.; Srivastava, A.; Coburn, K. R.; Faulkner, A. L.; Janusz, J. J.; Ridgeway, J. M.; Seibel, W. L. Tetrahedron Lett. 2004, 45, 619-621. doi:10.1016/j.tetlet.2003.10.177

43. Hassaneen, H. M. E. Synth. Commun. 2007, 37, 3579-3588. doi:10.1080/00397910701557564

44. de Paulis, T.; Hemstapat, K.; Chen, Y.; Zhang, Y.; Saleh, S.; Alagille, D.; Baldwin, R. M.; Tamagnan, G. D.; Conn, P. J. J. Med. Chem. 2006, 49, 3332-3344. doi:10.1021/jm051252j

45. Shawali, A. S.; Mosselhi, M. A.; Altablawy, F. M. A.; Farghaly, T. A.; Tawfik, N. M. Tetrahedron 2008, 64, 5524-5530. doi:10.1016/j.tet.2008.03.096

46. Rothenburg, E. Chem. Ber. 1894, 27, 685-691. doi:10.1002/cber.189402701133

47. Sato, T. J. Org. Chem. 1959, 24, 963-966. doi:10.1021/jo01089a019

48. Grey, E. J.; Stevens, H. N. E.; Stevens, M. P. G. J. Chem. Soc., Perkin Trans. 1 1978, 885-888.

49. Taylor, E. C.; Hartke, K. S. J. Am. Chem. Soc. 1959, 81, 2456-2464. doi:10.1021/ja01519a045

50. Echevarría, A.; Martín, M.; Pérez, C.; Rozas, I. Arch. Pharm. 1994, 327, 303-305. doi:10.1002/ardp.19943270507

51. Vaquero, J. J.; Fuentes, L.; Del Castillo, J. C.; Pérez, M. I.; García, J. L.; Soto, J. L. Synthesis 1987, 33-35. doi:10.1055/s-1987-27831

52. Hassanien, A. A.; Amar, A. E.; Ghozlan, S. A. S. J. Chin. Chem. Soc. 2000, 47, 1273-1278.

53. Elnagdi, M. H.; Abd Allah, S. O. J. Prakt. Chem. 1973, 315, 1009-1016. doi:10.1002/prac.19733150604

54. Arulsamy, N.; Bohle, D. J. Org. Chem. 2000, 65, 1139-1143. doi:10.1021/jo991614t

55. Shvekhgeimer, M.-G. A.; Ushakova, O. A. Chem. Heterocycl. Compd. 2001, 37, 370-371. doi:10.1023/A:1017527620923

56. Cankar, P.; Wiedermannova, I.; Slouka, J. Acta Univ. Palacki. Olomuc., Fac. Rerum Nat., Chem. 2002, 41, 7-15.

57. Dyachenko, V. D.; Tkachev, R. P. Russ. J. Org. Chem. 2006, 42, 149-171. doi:10.1134/S1070428002120011

58. Cheng, C. C.; Robins, R. K. J. Org. Chem. 1956, 21, 1240-1256. doi:10.1021/jo01117a010

59. Dooley, M. J.; Quinn, R. J.; Scammells, P. J. Aust. J. Chem. 1989, 42, 747-750. doi:10.1071/CH9890747
60. Elnagdi, M. H.; Hafez, E. A. A.; El-Fahham, H. A.; Kandeel, E. M. J. Heterocycl. Chem. 1980, 17, 73-76. doi:10.1002/jhet.5570170115

61. Larsen, J. S.; Zahran, M. A.; Pedersen, E. B.; Nielsen, C. Monatsh. Chem. 1999, 130, 1167-1173. doi:10.1007/PL00010295

62. Howe, R. K.; Bolluyt, S. C. J. Org. Chem. 1969, 34, 1713-1716. doi:10.1021/jo01258a040

63. Lu, R.-J.; Yang, H.-Z. Tetrahedron Lett. 1997, 38, 5201-5204. doi:10.1016/S0040-4039(97)01111-8

64. Kraybill, B. C.; Elkin, L. L.; Blethrow, J. D.; Morgan, D. O.; Shokat, K. M. J. Am. Chem. Soc. 2002, 124, 12118-12128. doi:10.1021/ja0264798

65. Kluge, R.; Schulz, M.; Pobišova, M.; Nüchter, M. Chem. Ber. 1994, 127, 1729-1733. doi:10.1002/cber.19941270924

66. Quinn, R. J.; Scammells, P. J.; Kennard, C. H. L.; Smith, G. Aust. J. Chem. 1991, 44, 1795-1801. doi:10.1071/CH9911795

67. Hassan, S. M.; Emam, H. A.; Abdelall, M. M. Phosphorus, Sulfur Silicon Relat. Elem. 2001, 175, 109-127. doi:10.1080/10426500108040260

68. Al-Afaleq, E. I.; Abubshait, S. A. Molecules 2001, 6, 621-638. doi:10.3390/60700621

69. Amer, A. A. Phosphorus, Sulfur Silicon Relat. Elem. 2008, 183, 2330-2343. doi:10.1080/10426500801963608

70. Aggarwal, R.; Kumar, V.; Singh, S. P. Indian J. Chem. 2006, 45B, 1426-1430.

71. Nilov, D. B.; Solov'eva, N. P.; Nikolaeva, I. S.; Peters, V. V.; Krylova, L. Y.; Gus'kova, T. A.; Granik, V. G. Pharm. Chem. J. 1998, 32, 358-361. doi:10.1007/BF02645992

72. Popil'nichenko, S. V.; Pil'o, S. G.; Brovarets, G. B. S.; Chernega, A. N.; Drach, B. S. Russ. J. Gen. Chem. 2005, 75, 1816-1820. doi:10.1007/s11176-005-0517-2

73. Shidlovskii, A. F.; Peregudov, A. S.; Averkiev, B. B.; Antipin, M. Y.; Chkanikov, N. D. Russ. Chem. Bull. 2004, 53, 2060-2070. doi:10.1007/s11172-005-0073-2

74. Shidlovskii, A. F.; Peregudov, A. S.; Bulychev, Y. N.; Chkanikov, N. D. Pharm. Chem. J. 2009, 43, 549-559. doi:10.1007/s11094-010-0349-1

75. Dodd, D. S.; Martinez, R. L.; Kamau, M.; Ruan, Z.; Van Kirk, K.; Cooper, C. B.; Hermsmeier, M. A.; Traeger, S. C.; Poss, M. A. J. Comb. Chem. 2005, 7, 584-588. doi:10.1021/cc049814s

76. Wardakhan, W. W.; Louca, N. A. J. Chil. Chem. Soc. 2007, 52, 1145-1149. doi:10.4067/S0717-97072007000200006

77. Dawood, K. M. J. Chem. Res., Synop. 1998, 128-129. doi:10.1039/A706107B

78. Organ, M. G.; Mayer, S. J. Comb. Chem. 2003, 5, 118-124. doi:10.1021/cc020045r

79. Velcicky, J.; Feifel, R.; Hawtin, S.; Heng, R.; Huppertz, C.; Koch, G.; Kroemer, M.; Moebitz, H.; Revesz, L.; Scheufler, C.; Schlapbach, A. Bioorg. Med. Chem. Lett. 2010, 20, 1293-1297. doi:10.1016/j.bmcl.2009.10.138

80. Rzepecki, P.; Gallmeier, H.; Geib, N.; Cernovska, K.; König, B.; Schrader, T. J. Org. Chem. 2004, 69, 5168-5178. doi:10.1021/jo0496603

81. Bagley, M. C.; Davis, T.; Dix, M. C.; Murziani, P. G. S.; Rokicki, M. J.; Kipling, D. Bioorg. Med. Chem. Lett. 2008, 18, 3745-3748. doi:10.1016/j.bmcl.2008.05.037

82. Elmoghayar, M. R. H.; Elghandour, A. H. H. Monatsh. Chem. 1986, 117, 201-204. doi:10.1007/BF00809440

83. Bondock, S.; Rabie, R.; Etman, H. A.; Fadda, A. A. Eur. J. Med. Chem. 2008, 43, 2122-2129. doi:10.1016/j.ejmech.2007.12.009

84. Hutaud, D. H.; Baudy-Floc'h, M.; Gougeon, P.; Gall, P.; Le Grel, P. Synthesis 2001, 2435-2440. doi:10.1055/s-2001-18723 
85. Beam, C. F.; Davis, S. E.; Cordray, T. L.; Chan, K. W.; Kassis, C. M.; Freeman-Davis, J. G.; Latham, G. M.; Guion, T. S.; Hilderbran, K. C.; Church, A. C.; Koller, M. U.; Metz, C. R.; Pennington, W. T.; Schey, K. L. J. Heterocycl. Chem. 1997, 34, 1549-1554. doi:10.1002/jhet.5570340527

86. Neidlein, R.; Li, S. J. Heterocycl. Chem. 1996, 33, 1943-1949. doi:10.1002/jhet.5570330663

87. Unverferth, K.; Engel, J.; Höfgen, N.; Rostock, A.; Günther, R.; Lankau, H.-J.; Menzer, M.; Rolfs, A.; Liebscher, J.; Müller, B.; Hofmann, H.-J. J. Med. Chem. 1998, 41, 63-73. doi:10.1021/jm970327j

88. Fouqué, D.; About-Jaudet, E.; Collingnon, N. Synth. Commun. 1995, 25, 3443-3455. doi:10.1080/00397919508013868

89. Abdelhamid, A. O.; Zohdi, H. F.; Sallam, M. M.; Ahmed, N. A. Molecules 2000, 5, 967-973. doi:10.3390/50700967

90. Abdelhamid, A. O. J. Chem. Res., Synop. 1993, 208-209.

91. Ioannidou, H. A.; Koutentis, P. A. Tetrahedron 2009, 65, 7023-7037. doi:10.1016/j.tet.2009.06.041

92. Shokol, T. V.; Turov, V. A.; Semeniuchenko, V. V.; Krivokhizha, N. V.; Khilya, V. P. Chem. Heterocycl. Compd. 2006, 42, 500-505. doi:10.1007/s10593-006-0117-z

\section{License and Terms}

This is an Open Access article under the terms of the Creative Commons Attribution License

(http://creativecommons.org/licenses/by/2.0), which permits unrestricted use, distribution, and reproduction in any medium, provided the original work is properly cited.

The license is subject to the Beilstein Journal of Organic Chemistry terms and conditions:

(http://www.beilstein-journals.org/bjoc)

The definitive version of this article is the electronic one which can be found at: doi:10.3762/bjoc. 7.25 